\title{
LEGAL FRAMEWORK, TRENDS, AND DEVELOP, MENTS IN INVESTMENT PRACTICES OF LIFE INSURANCE COMPANIES
}

\author{
Haughton Bell* and Harold G. Fraine $\dagger$
}

Changes have taken place, as the title indicates, and are still taking place, both in the laws governing the investment of life insurance funds and in the practices of the companies in making such investments. The changes in practice, in turn, not only result from the changes in laws but are also, possibly to an even more important extent during the past 25 years, changes which have been made by the companies within the framework of existing statutory provisions.

It will be the purpose of this article to trace these changes, especially those which have occurred since the late twenties, and also to assess them in the light of what appears to be the interest of the public, and, particularly, the interest of life insurance policyholders. The policyholders are presently estimated to number approximately 55 per cent of the people in the United States, and with their beneficiaries cover a

${ }^{2}$ LIfE Insurance FACr Book, 195 I 5 (Institute of Life Insurance, New York City). much larger proportion of the population.

In order to appreciate the development of life insurance investment, it is necessary to view it in perspective. It is only in this way that the scope and significance of the changes which have been taking place in investment laws and investment practices can be understood and evaluated.

\section{Background of Legal Framework}

The legal framework, of course, controls the areas within which investments may be made. A life insurance company's investments are governed directly by the laws of the state of its domicile. The single exception is investments in real estate, where the laws of the situs also directly affect the legality of the investment.

Life insurance companies domiciled in just 6 states have since the turn of the century accounted for between 80 per cent and 90 per cent of the assets, and therefore of the investment funds, of all legal reserve life insurance companies in the United States. These 6 states are New York, New Jersey, Massachusetts, Connecticut, Wisconsin, and Pennsylvania and their relative importance is shown in Table $\mathrm{r}$.

- A.B. I9r7, LL.B. I922, Harvard University. Vice President and General Counsel, The Mutual Life Insurance Company of New York, since r950. Formerly associated with firm of Root, Clark Buckner, Howland, and Ballantine, New York City, 1923-r933. Assistant Financial Manager, The Mutual Life Insurance Company of New York, I933-r938; Assistant General Counsel, I938-1950. Contributor to insurance and financial periodicals.

+Com.E. 1926, University of Cincinnati; Ph.D. I937, University of Minnesota. Professor of Commerce, University of Wisconsin since I948. Previously assistant director of research for the Life Insurance Investment Research Committee and head of the Research Section of the Trading and Exchange Division of the Securities and Exchange Commission. Co-author, Study of Bank Enrning Assets (I938); Personnel Program for Banks (I939); Corporate Bond Statistics (i94I). Contributor to financial periodicals. 
Table I. Admitted Assets of Life Insurance Companizs Domiciled in 6 States

\begin{tabular}{|c|c|c|c|c|c|c|c|c|c|c|c|c|}
\hline & \multicolumn{6}{|c|}{ Mildions of Dollars } & \multicolumn{6}{|c|}{$\begin{array}{l}\text { PERCENT OF ALL } \\
\text { U. S. CoMpanIES }\end{array}$} \\
\hline & 1906 & 1916 & 1928 & 1935 & 1940 & 1950 & 1906 & 1916 & 1928 & 1935 & 1940 & 1950 \\
\hline 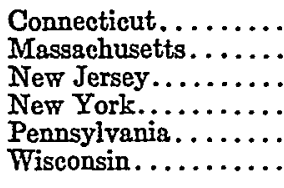 & $\begin{array}{r}223 \\
178 \\
234 \\
1,700 \\
191 \\
221\end{array}$ & $\begin{array}{r}345 \\
405 \\
640 \\
2,824 \\
324 \\
367\end{array}$ & $\begin{array}{r}1,198 \\
1,265 \\
2,562 \\
6,470 \\
812 \\
871\end{array}$ & $\begin{array}{l}1,801 \\
1,881 \\
3,739 \\
9,880 \\
1,160 \\
1,118\end{array}$ & $\begin{array}{r}2,595 \\
2,635 \\
5,045 \\
12,779 \\
1,495 \\
1,421\end{array}$ & $\begin{array}{r}6,029 \\
6,269 \\
10,304 \\
24,225 \\
2,604 \\
2,705\end{array}$ & $\begin{array}{r}7.6 \\
6.1 \\
8.0 \\
58.1 \\
6.5 \\
7.6\end{array}$ & $\begin{array}{r}6.2 \\
7.3 \\
11.6 \\
51.0 \\
5.9 \\
6.6\end{array}$ & $\begin{array}{r}7.5 \\
7.9 \\
16.1 \\
40.5 \\
5.1 \\
5.5\end{array}$ & $\begin{array}{r}7.8 \\
8.1 \\
16.1 \\
42.6 \\
5.0 \\
4.8\end{array}$ & $\begin{array}{r}8.4 \\
8.6 \\
16.4 \\
41.5 \\
4.9 \\
4.6\end{array}$ & $\begin{array}{r}9.5 \\
0.8 \\
16.2 \\
38.0 \\
4.1 \\
4.2\end{array}$ \\
\hline Six-State Total. & 2,747 & 4,905 & 13,178 & 19,579 & 25,970 & 52,136 & 93.9 & 88.6 & 82.6 & 84.3 & 84.3 & 81.8 \\
\hline All U. S. Companies & 2,924 & 5,537 & 15,961 & 23,216 & 30,802 & 63,699 & 100.0 & 100.0 & 100.0 & 100.0 & 100.0 & 100.0 \\
\hline
\end{tabular}

Note: Detail may not add to totals due to rounding.

Source: From data supplied by the Division of Research \& Statisties of the Institute of Lifo Insurnnce, Now York City.

The laws of those states have, consequently, by and large, established the legal framework for life insurance investments. Laws of states in which companies are licensed to do business, however, may have an indirect effect on their investments, since it is not uncommon for them to provide that a license may be refused a foreign insurer if its investments do not comply in substance with the investment requirements and limitations imposed by law upon domestic insurers. The area of latitude which a foreign company enjoys in such a state beyond that of a domestic company necessarily depends, to some extent at least, on the policy of administration followed by the state insurance department, but in the main, it must confine itself to the investments permitted to domestic companies.

When the number of life insurance companies domiciled in New York state is added to the others that are licensed to do business there, it is found that together they account for 84.6 per cent ${ }^{2}$ of the assets of all United States legal reserve life insurance companies. Since New York has a provision requiring substantial compliance by foreign insurers with its investment laws, ${ }^{3}$ and, since its investments laws have consistently been among the strictest in the United States, its laws have had a more important influence than the laws of any other state in marking out the areas in which life insurance funds may be invested.

\section{INFLUENCE of the ARMstrong or Hughes Investigation}

Any study of life insurance investments in this country must, almost necessarily, start with at least a passing reference to the Armstrong or Hughes investigation of life insurance companies which took place in New York in rg05. Before that investigation, there had been wide latitude permitted the companies in the matter of investments. The investigation disclosed the abuses which had arisen through the participation of life insurance companies, in common with their officers and di-

2 As of December 31, 1950. In 1906, the figure was $97.5 \%$. (Source: Institute of Life Insurance).

3 N. Y. INs. LAW \$90.T. 
rectors, in underwriting syndicates and as a result of the control through stock ownership by life insurance companies of other corporations, including banks and mortgage companies, in which directors and officers of the life insurance companies had stock interests. ${ }^{4}$ The laws enacted in New York immediately after this investigation swung the pendulum far in the opposite direction and limited life insurance investments to public debt obligations, including those of the Federal Government, states, counties, and other political subdivisions, adequately secured corporate bonds, mortgage loans secured by improved and unencumbered real estate worth 50 per cent more than the amount loaned, and such real property as might be needed for company occupancy. Real estate acquired in satisfaction of debt had to be disposed of within 5 years from the time it was acquired, unless the Superintendent of Insurance granted an extension on the ground of hardship. ${ }^{5}$ Companies were also required ${ }^{6}$ to make loans to their own policyholders upon the security of their policies of sums not exceeding the legal reserve required on the policy. Investments were not permitted in stocks, in income producing real property, in unsecured corporate obligations, or in obligations of unincorporated organizations or individuals unless secured by real estate mortgage or by collateral in which investments could be made directly.

The laws of Wisconsin were even more strict, corporate investments being confined to adequately secured bonds of railroad and street railroad companies and, commencing in I9I7, public utility corporations. ${ }^{7}$

Pennsylvania limited investments of reserves to bonds or notes of railroad companies, and water, gas or other public utility companies, but permitted assets over and above capital and reserve requirements to be invested, within limits, in standard and listed stocks or other evidences of indebtedness of solvent corporations. ${ }^{8}$

New Jersey permitted investments in capital stock, bonds, securities or other evidences of indebtedness of corporations, subject to limitations which included a dividend paying test in the case of stocks. ${ }^{9}$

Massachusetts required that three-quarters of a life insurance company's reserves be invested in areas similar to those prescribed by the New York law, but there was wide latitude permitted to Massachusetts companies with respect to the remainder of the company's assets and this could be invested within broad limits in the discretion of the directors. ${ }^{10}$

Connecticut also had a fairly liberal investment law which included equity investments, subject to a dividend paying test. ${ }^{11}$

All permitted investments in public debt obligations and in real estate mortgage loans up to 50 per cent to $66 \% 3$ per cent of the value of the security.

\footnotetext{
"State of New York, Testimony, Exhibits, and Report of Legislative Insurance Investigating Commattee (I905).

${ }^{5}$ N. Y. Laws 1906, c. $326, \$ \S 5,6$, and 36 . 'Id. $\$ 37$.

Wis. Laws 1903, c. 6 ; id. 19I7, c. 270 .

N. J. Laws 1902, c. 134, §16.

Id. $\$ 37$.
$\mathrm{Pa}$. Laws I9II, 567, $\$ 19-20$.

${ }^{11}$ Conn. Laws 1889, c. 98 .

${ }^{10}$ Mass. Laws 1907 , c. $576, \$ 37$.
} 


\section{The Situation IN I928}

There were no changes of any real significance in the legal framework until Ig28. Up to that time, life insurance investments-whether as a result of the requirements of law or the investment policies followed by the companies themselveswere in actual fact confined almost entirely to public debt obligations, mortgages secured by improved and unencumbered real estate, and corporate bonds adequately secured by physical property or collateral other than corporate stocks. As the year of 1927 drew to a close, the life insurance business had 43.I per cent of its assets concentrated in real estate mortgage loans, as judged by the holdings of 49 companies which had 9I.3 per cent of the assets of all United States legal reserve life insurance companies. ${ }^{12}$ The mortgages on urban properties aggregated about twice those on farm properties. The investments in corporate obligations came next in importance, constituting 28.6 per cent of the assets. Policy loans and premium notes absorbed I2.I per cent of the assets. Public debt obligations comprised only 6.I per cent of total assets, with the United States Government bonds only slightly exceeding those of the states, counties, and municipalities. Canadian Government bonds represented 2.3 per cent of assets. Thus, over 92 per cent of all investments were in the form of such debt obligations as mortgages and corporate and United States Government bonds. All other types were small in amount: real estate represented less than 2 per cent of total assets; stocks, principally common, only $x .2$ per cent; cash, slightly less than I per cent; and all other assets, including principally accrued interest, uncollected and deferred premiums, and foreign government bonds, made up the balance.

Up to this time, the safest corporate investments were generally considered to be the obligations of the regulated industries, namely railroads and public utilities, which were traditionally secured by mortgages on physical property. Investments in both of these fields can be found in substantial volume in the portfolios of life insurance companies as far back as the turn of the century and even earlier. ${ }^{13}$ Railroads had reached their maturity before the financing of public utilities had attained sub. stantial volume and the bulk of the corporate investments, even as late as 1927 , were in railroad bonds. Although investments had been made for many years in the bonds of water companies, gas companies, and telephone companies, ${ }^{14}$ it was in the twenties that the financing of electric and power companies assumed a role of major importance. By the close of 1927 the total holdings of public utility investments had reached about half the holdings of railroad securities. Up to the end of the twenties, however, there were very few investments in the obligations of industrial or commercial companies. At the end of 1927 , these constituted only 1.2 per cent of total assets.

\footnotetext{
${ }^{12}$ Except where otherwise noted the figures in this and the next two paragraphs were obtained from Proceedings of the Forty-fourth Anvial Meeting of the Life Insurance Association of Amenica 39-42 (1950).

${ }^{13}$ Lester W. Zartman, The Investaments of Life Insuranice Companies (1906).

11 Ibid.
} 


\section{Changes-ig28 to Date}

This was the setting in rg28. In that year the New York law was amended ${ }^{15}$ so that, instead of corporate investments being confined to secured obligations, life insurance companies were permitted to invest in unsecured corporate obligations and preferred stocks, provided the earnings of the issuer applicable to dividends during each of 3 , including the last 2, of the 5 preceding years were equal to 4 per cent on its capital stock. This was a most significant change and, since the most important as well as the most interesting changes in trends and developments in investment practices took place after that time, the balance of this study will be confined to the tracing of the developments in this later period, and consideration of the investment problem with which the industry now appears to be confronted.

The economic characteristics of the period following 1928 which have affected investment operations may be outlined briefly. The boom of the late twenties came to an abrupt end and the first half of the thirties was a period of deep depression. During that period, there was little demand for investment funds by industry. Furthermore, although the assets of the life insurance industry did not cease to grow, there was little growth between the end of I93I and the end of I933. By I933, the decline in the interest rate had become pronounced and this decline continued without interruption for the next 15 years.

From I934 on, the demands of industry for investment funds commenced to revive and continued, with some setback in 1938 , through $194 \mathrm{I}$. This was a period in which there were substantial refundings of outstanding corporate obligations to take advantage of the lower interest rates. The revival of corporate demand and the period of refundings came at a time when there was a very large volume of investment funds seeking outlets. The lower interest rates made debt obligations less attractive to private investors, and many sought the safety which the diversified investments of insurance companies and other institutions provided. The latter half of the thirties was also a period of mortgage foreclosures and of sales by the life insurance companies of the real estate which they acquired in satisfaction of debt. Foreclosures and liquidation of foreclosed real estate holdings continued during the early part of the forties.

The first half of the forties was completely dominated by the growth of the federal debt to meet the requirements of the War. It was a period in which industry's investment demands were minor, and virtually all of the increase in investments made by the life insurance companies was in United States Government bonds.

The last half of the forties was a period of the greatest capital formation in the history of the world. Not only were funds required by industry of all types for reconversion, but they were also needed to meet the pent-up requirements for expansion and even, to some extent, for replacement and modernization which had been built up during the war and the depressions of the thirties. Most of these capital

${ }^{18}$ N. Y. Laws I928, c. 539. 
requirements were financed internally, that is, through depreciation reserves and, to an even greater extent, retained earnings. ${ }^{16}$ Nevertheless, investors were called upon to furnish a greater volume of dollars for industry and private construction during this period than in any previous period of similar length. These demands not only absorbed all of the new funds of the life insurance companies, but also absorbed those which resulted from a conversion of the low-yielding Government bonds acquired during the War into higher-yielding forms of securities.

This demand appeared to be tapering off during the latter part of 1949 and the early months of I950, but the outbreak of hostilities in Korea again stimulated the demand for funds in industry. During that year corporations spent an estimated I8.I billion dollars on new investment and the nation built an estimated $x, 395,000$ dwelling units. ${ }^{17}$

As the demand for investment funds by corporations rose during the latter half of the forties, the interest rate, which reached an all time low in 1947 , began very slowly to rise. ${ }^{18}$ This reversal of trend was given further stimulus early in 1951, when the Federal Reserve withdrew its rigid support of the price of Government bonds. This, at least temporarily, slowed up the conversion of the life insurance industry's Government bonds. Credit restrictions, largely voluntary, during the past few months also tended to reduce the rate of new investment.

\section{Life Insurance Companies and the Capital Market}

An understanding of the investment trends and developments which have taken place during the period under study also requires consideration of the change in the relationship between the total volume of life insurance funds, and also the funds of other investors competing with them in the search for investment outlets, on the one hand, and the total supply of media which have constituted the traditional forms of investment, on the other. ${ }^{19}$ This change has been profound and has greatly influenced the changes which have taken place during the period both in investment laws and in company practices. The causes of this change in relationship appear still to be operative and point up what is probably one of the principal problems confronting the life insurance business today-the finding of new investment outlets yielding an income sufficient to keep the net cost of insurance to policyholders as low as is consistent with the safety of the investment.

\footnotetext{
${ }^{10}$ Jornt Committee Print, Factors Affecting Volume and Stability of Private Investment, Materials on the Investacent Problem (8ist Cong., rst Sess. 1949).

${ }^{17}$ Minutes of Public Hearings of the New York State Joint Legislative Committee on INsurance Rates and Regulation [hereinafter Minutes of Public Hearings] 286 (Feb. 9, $195 x$ ).

${ }^{18}$ The net yield on life insurance assets, $5.0 \%$ in 1930 , dipped to a low of $2.8 \%$ in 1947 , and recovered to $3.03 \%$ in 1950 . (Source: Metropolitan Life Insurance Company). See Hearings before the Joint Committee on the Economic Report on Volume and Stability of Private Investment, Pf. 2, 8Ist Cong., Ist Sess. 206 (r949). Yield on new investments is not available.

19 The principal relationships of institutions to the capital market since r920 have been described in another paper for this symposium-Charles H. Schmidt and Eleanor J. Stockwell, The Changing Importance of Institutional Investors in the American Capital Market, supra. The comments in this paper can therefore be confined to points requiring greater elaboration.
} 
Long-term debt obligations have always, even prior to the Armstrong investigation, comprised the bulk of life insurance investments. However, it has only been in war and postwar periods, including the Civil War, as well as World War I and World War II, and during the comparative dearth of other investments in the latter half of the thirties, that life insurance funds have been invested to any substantial extent in public debt obligations. Public debt, even long-term public debt, normally yields a very low return, due to the strength of the credit. This situation is now accentuated by the Government's policy regarding the management of the federal debt and by the tax exempt features of state and local public debt which make it particularly attractive to certain types of private investors, and hence correspondingly high priced to others. As life insurance funds are forced to go into public debt, the cost of insurance to the nation's policyholders, therefore, progressively increases over what it would otherwise be. This accounts for the fact that it has been used as an investment medium for life insurance funds only in emergencies or where no other form of outlet was available, except to the degree that it has been held for purposes of providing liquidity. Consequently, although it is quite naturally a permissible investment under all life insurance investment statutes, it is only subject to the qualifications just mentioned that it may be said to be one of the traditional outlets for life insurance funds.

The most important point to consider, therefore, in connection with the change in relationship between supply of and demand for life insurance investment funds is the relationship between long-term private debt, on the one hand, and life insurance funds and the funds of other. investors competing with them for the same type of investment outlets, on the other.

Again, present trends can best be understood by viewing this relationship in perspective. The relationship for life insurance funds alone is shown in Table 2. The dates chosen in that Table are confined to I906, the year in which the Armstrong Committee Report was published; $19 \mathrm{I} 6$, the year immediately preceding the entry of the United States into the first World War; I927, the year preceding the amendment to the New York Insurance Law permitting investment in unsecured corporate obligations and preferred stocks; and 1950, the last calendar year preceding the writing of this paper.

From Table 2, the radical change in relationship becomes strikingly apparent. At the end of rgo6, the total life insurance assets in the United States were only about 13.2 per cent of the gross long-term private debt, and approximately ix per cent of the gross public debt (long-term and short-term) and gross long-term private debt in the United States. ${ }^{20}$ In 1927 , total assets were only about 18 per cent of net long-term private debt, and 13 per cent of net long-term public and private debt. At the end of 1950 , the assets were approximately 54 per cent of net long-term

${ }^{20}$ Only slightly over $4 \%$ of the assets of the 49 life insurance companies whose assets then totalled $97.7 \%$ of the industry's assets were actually invested in the public debt in the United States, only . $1 \%$ being in federal debt. 
Tarle 2. Assets of U. S. Life Companies and Net Long-Term Debt in U. S.

\begin{tabular}{|c|c|c|c|c|c|c|c|}
\hline \multirow{2}{*}{ December 31} & \multirow{2}{*}{$\begin{array}{c}\text { Assets } \\
\text { of Life } \\
\text { Companies }\end{array}$} & \multicolumn{3}{|c|}{ Net LoNa-Terar DeBt } & \multicolumn{3}{|c|}{ Assets As \% of Dent } \\
\hline & & Private* & Public & Total & Private & Public & Total \\
\hline $\begin{array}{l}1906 \ldots \ldots \ldots \ldots \\
1916 \ldots \ldots \ldots \ldots \\
1927 \ldots \ldots \ldots \ldots \\
1950 \ldots \ldots \ldots \ldots\end{array}$ & $\begin{array}{c}\text { (\$ bil.) } \\
2.9 \\
5.5 \\
14.4 \\
64.0\end{array}$ & $\begin{array}{c}\text { (\$ bil.) } \\
22.0^{* *} \\
43.4 \\
81.5 \\
119.2\end{array}$ & $\begin{array}{c}(\$ \text { bil. }) \\
4.2^{* *} \\
5.3 \\
28.0 \\
219.1\end{array}$ & $\begin{array}{c}(\$ \text { bil. }) \\
26.2^{* *} \\
48.7 \\
109.5 \\
338.3\end{array}$ & $\begin{array}{l}(\%) \\
13 \\
13 \\
18 \\
54\end{array}$ & $\begin{array}{c}(\%) \\
69 \\
104 \\
51 \\
29\end{array}$ & $\begin{array}{l}(\%) \\
11 \\
11 \\
13 \\
10\end{array}$ \\
\hline
\end{tabular}

* Net Long-Term Private Debt: All private net corporate debt outstanding at end of year having an original maturity of ono year or more from the date of issue (including bonds and mortgages) plus mortgage debt of individuals and unincorporated busincsses, including farms.

* Gross debt. Public debt includes short-term.

Sources: Institute of Life Insurance, U. S. Department of Commerce, U. S. Department of Agriculture, U. S. Treasury Department, and National Industrial Conference Board. This Table, Tables 3, 4, and 5, and Charts I and II were prepared by the Research Division of The Miutual Life Insurance Company of New York under the direction of Donald B. Woodward, Second Vico Presideat, and Mrs. Eleanor S. Bagley, Research Associate.

private debt and Ig per cent of net long-term public and private debt.

A truer picture of the change in relationship between the supply and demand can be seen by comparing the aggregate of life insurance funds and the funds of other investors which compete for the same types of investments, with the total supply of net long-term private debt. Table 3 gives the comparison between the total funds of life insurance companies and the other two institutional investors, mutual savings banks and savings and loan associations, which are confined principally to the same types of investments. It does not, however, include the funds of other investors, such as commercial banks, fire, casualty and marine and other insurance companies, investment trusts, personal trusts administered by trust companies and personal trustees, university, school and other endowment funds, or pension trusts-all investors who, while they do compete with part of their funds for the same types of investments, are not as closely confined to those types as the institutions whose assets are included in the Table. Table 3 thus understates substantially probably both the ratio of competing funds to net long-term private debt and the rate of growth of the demand. Inclusion of these other funds, or even that portion of them which in fact competes, would, of course, show a total in excess of present long-term private debt. Pension funds alone, excluding those carried in life insurance companies, are estimated to be increasing at the rate of about one billion dollars a year. In view of the rapidity of growth of investment trusts and pension trusts in recent years, the rate of growth of the demand for, versus the supply of, investment media shown in Table 3 would appear to be even higher than that indicated by the Table. Additional figures relating to this comparison are included in the first paper in this symposium, on "The Changing Importance of Institutional Investors in the American Capital Market."

It is easy to see from the situation revealed in Tables 2 and 3 that one prime characteristic of the whole period from the depression to the recent relaxation by the Federal Reserve of its rigid support of the Government bond market is that it has been a borrower's market in which competition by institutions to get their money in- 
Table 3. Savings Institution Assets* and Net Long-Term Private Debt

\begin{tabular}{|c|c|c|c|}
\hline December 31 & $\begin{array}{c}\text { Savings Institution } \\
\text { Assets }\end{array}$ & $\begin{array}{l}\text { Net Long-Term } \\
\text { Private Debt }\end{array}$ & Assets as \% of Debt \\
\hline $\begin{array}{l}1906 \ldots \ldots \ldots \ldots \ldots \ldots \\
1916 \ldots \ldots \ldots \ldots \ldots \ldots \ldots \\
1927 \ldots \ldots \ldots \ldots \ldots \ldots \\
1950 \ldots \ldots \ldots \ldots \ldots \ldots\end{array}$ & $\begin{array}{c}\text { (\$ bil.) } \\
\text { not available } \\
11.5 \text { (est.) } \\
30.6 \\
103.3\end{array}$ & $\begin{array}{c}\text { (\$ bil.) } \\
43.4 \\
81.5 \\
125.1\end{array}$ & $\begin{array}{l}\% \\
26 \\
38 \\
83\end{array}$ \\
\hline
\end{tabular}

*Life insurance companies, mutual savings banks, and savings and loan associations.

Sources: Institute of Life Insurance, Federal Home Loan Bank, Comptroller of Currency, Board of Governors of the Federal Reserve System, and U. S. Department of Commerce.

vested has been extremely keen. It is scarcely possible to avoid the suspicion also that, at least for part of the period, institutional investors of all kinds who were confined largely to the field of debt obligations have, making full allowance for the Government's money policy, been paying something for legality as distinguished from investment quality. ${ }^{21}$ The differential in cost is ultimately stood by the great body of the nation's policyholders.

As might also be expected, the period since r 928 has been one during which the life insurance industry has been exploiting to the full the areas of permissible investments in the traditional forms. This has been necessary in order to try to provide, under lower interest rates and higher costs, the growth of reserves required by policy contracts written during earlier periods of higher interest rate assumptions. Without such an effort, inflation of costs and artificially low interest rates would have raised the cost of insurance under new contracts more than they have. This period of great relative reduction in supply of traditional investment media has been also characterized by only slight changes in the legal framework. The slight changes that have been made represent a further bursting out from the molds into which life insurance investments were cast in the post-Armstrong days, even as these were relaxed by the amendments and practices commencing in the late twenties.

The changes in the legal framework which have taken place in the past 25 years may be described briefly. The more important changes were: (I) the inclusion within the legal areas of 80 per cent and 90 per cent mortgages insured by the F.H.A., permitted during the middle thirties and early forties, and mortgages guaranteed by the V.A., permitted during the forties; (2) some relaxation in the earnings' tests for corporate securities, permitted during the late thirties; (3) the inclusion of investments in large scale rental housing projects for low and moderate income groups, in some cases with maximum returns roughly comparable to those earned on mortgage loans, permitted during the late thirties and early forties; and (4) the inclusion of a limited amount of investment in income-producing real estate, fre-

\footnotetext{
${ }^{21}$ See Report by the TRUST INvestiment Study Committee 54, 62 (Trust Division, N. Y. State Bankers Ass'n, 1950). That report also brings out well the differential which has existed between common stock yields and debt yields. See also Hearings before the Joint Committee on the Economic Report, supra note 18 , at 394,395 .
} 
quently excluding that used primarily for agricultural, ranch, mining and amusement purposes, initiated by a Virginia statute in 1942 and widely permitted during the middle forties. ${ }^{22}$ (5) Other special types of investments, such as obligations of the International Bank for Reconstruction and Development, have been generally added to permissible investments. By far the most significant amendments have opened up to a limited but increasing extent (6) investments in common stocks, now legal in $3^{6}$ states, 12 having been added to this list since 1940 ; and (7) investments subject to no legal restrictions, i.e., investments within the discretion of management, permitted in a series of amendments in I4 states, commencing in $1945{ }^{23}$

In the main, however, from I 906 to the present time, life insurance investments have been confined, with relatively minor exceptions, to corporate debt, real estate mortgage debt, and, to a lesser extent, public debt obligations. This can be seen, in summary form, from Table 4 and Chart $I$, showing the changes in assets which have taken place, particularly in the period since I927.

The figures alone in Table 4 and Chart I, if studied closely, tell part of the story of the trends and developments which have been taking place during the past 25 years within the comparatively little-changed legal framework. But it is only part of the story and the bare figures conceal much of it, particularly the revolutionary changes which have occurred in investment analysis and lending methods.

The figures themselves are deserving of some comment. The differences between the changes in percentage figures and in dollar holdings since 1927 are differences which might be expected with the rapid growth of life insurance assets, but they are, nevertheless, noteworthy. The greatest changes both percentagewise and dollarwise have taken place in the holdings of United States Government bonds and in the holdings of industrial and miscellaneous corporate bonds; and it is the latter change which provides the most interesting story. Public utility bonds slightly more than doubled percentagewise but increased almost nine-fold dollarwise. The dollar holdings of railroad bonds increased slightly, but percentagewise they represent little more than one-quarter of the 1927 investment. The percentage holdings of real estate mortgages also declined substantially, but the dollar volume increased approximately two and one-half times. Although the dollar holdings of real estate increased approximately four times since $x 927$ (with a larger bulge during the foreclosures of the thirties and early forties), they still represent only about 2 per cent of assets. Investments in stocks have increased from the relatively small figure of I02 million dollars to 2.I billion dollars (of which only about one fourth consists of common stock), but still constitute only about 3 per cent of assets. There has been a slight increase in the dollar volume of policy loans and premium notes, but percentagewise they have fallen from over I2 per cent to less than 4 per cent, with, again,

${ }^{22}$ VA. Code ANn. $\$ 4258 \mathrm{a}$ (1942); see Satterthwaite, Investments by Life Insurance Companies in Real Estate, Ins. L. J. 771-783 (Sept. 1947); Cary, Corporate Financing Through the Sale and Lease-Back of Property: Business, Tax and Policy Considerations, 62 Harv. L. Rev. I-41 (1948).

${ }^{23}$ See William R. Shands, Investment Laws-Changes During Last Decade (paper read beforc the Association of Life Insurance Counsel, Dec. r1, 1946). 
Tabie 4. U. S. Life Insurance Company Asset Distribution DECEMBER $3^{\text {I }}$

\begin{tabular}{|c|c|c|c|c|c|c|c|c|}
\hline & \multicolumn{8}{|c|}{ Miluions of Dolinars } \\
\hline & 1906* & $1916^{*}$ & 1927 & 1932 & 1934 & 1940 & 1945 & 1950 \\
\hline 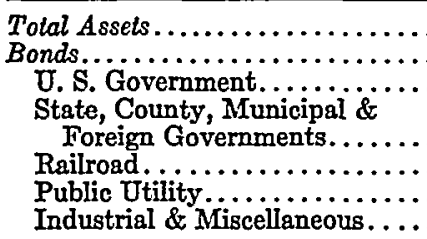 & $\begin{array}{r}2,858 \\
1,308 \\
3 \\
191 \\
958 \\
117 \\
34\end{array}$ & $\begin{array}{r}5,322 \\
2,398 \\
1 \\
450 \\
1,637 \\
203 \\
47\end{array}$ & $\begin{array}{r}14,892 \\
5,078 \\
471 \\
741 \\
2,528 \\
1,179 \\
159\end{array}$ & $\begin{array}{r}20,754 \\
6,766 \\
465 \\
1,339 \\
2,851 \\
1,742 \\
369\end{array}$ & $\begin{array}{r}21,844 \\
8,460 \\
1,881 \\
1,591 \\
2,706 \\
1,846 \\
436\end{array}$ & $\begin{array}{r}30,802 \\
16,889 \\
5,857 \\
2,502 \\
2,820 \\
4,264 \\
1,540\end{array}$ & $\begin{array}{l}44,797 \\
32,605 \\
20,583 \\
1,898 \\
3,009 \\
5,212 \\
1,903\end{array}$ & $\begin{array}{r}63,984 \\
39,345 \\
13,444 \\
2,605 \\
3,187 \\
10,585 \\
9,524\end{array}$ \\
\hline \multirow[t]{3}{*}{ 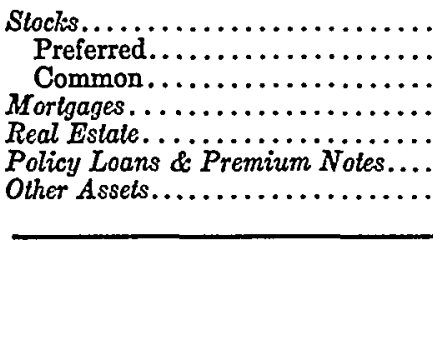 } & $\begin{array}{r}131 \\
18 \\
113 \\
810 \\
156 \\
258 \\
205\end{array}$ & $\begin{array}{r}78 \\
12 \\
66 \\
1,774 \\
144 \\
746 \\
242\end{array}$ & $\begin{array}{r}102 \\
25 \dagger \\
77 \dagger \\
6,184 \\
350 \\
1,785 \\
893\end{array}$ & $\begin{array}{r}524 \\
424 \dagger \\
100 \dagger \\
7,316 \\
934 \\
3,806 \\
1,408\end{array}$ & $\begin{array}{r}438 \\
354 \dagger \\
84 \dagger \\
5,857 \\
1,689 \\
3,658 \\
1,742\end{array}$ & $\begin{array}{r}554 \\
417 \dagger \\
137 \dagger \\
5,958 \\
2,060 \\
3,091 \\
2,156\end{array}$ & $\begin{array}{r}999 \\
819 \\
180 \\
6,686 \\
857 \\
1,962 \\
1,738\end{array}$ & $\begin{array}{r}2,126 \\
1,541 \\
585 \\
16,097 \\
1,448 \\
2,414 \\
2,660\end{array}$ \\
\hline & \multicolumn{8}{|c|}{ Percent of Total Assets } \\
\hline & $1906^{*}$ & $1916^{*}$ & 1927 & 1932 & 1934 & 1940 & 1945 & 1950 \\
\hline 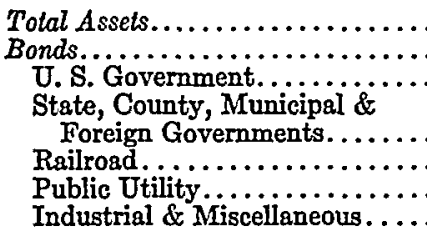 & $\begin{array}{r}100 \\
46 \\
0 \\
7 \\
34 \\
4 \\
1\end{array}$ & $\begin{array}{r}100 \\
44 \\
0 \\
8 \\
31 \\
4 \\
1\end{array}$ & $\begin{array}{r}100 \\
35 \\
3 \\
5 \\
18 \\
8 \\
1\end{array}$ & $\begin{array}{r}100 \\
39 \\
2 \\
7 \\
14 \\
8 \\
2\end{array}$ & $\begin{array}{r}100 \\
38 \\
9 \\
7 \\
12 \\
8 \\
2\end{array}$ & $\begin{array}{r}100 \\
55 \\
19 \\
8 \\
9 \\
14 \\
5\end{array}$ & $\begin{array}{r}100 \\
73 \\
46 \\
4 \\
7 \\
7 \\
12 \\
4\end{array}$ & $\begin{array}{r}100 \\
62 \\
21 \\
\\
4 \\
5 \\
17 \\
15\end{array}$ \\
\hline 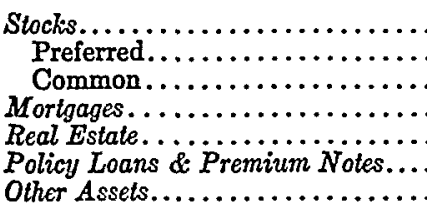 & $\begin{array}{r}5 \\
1 \\
4 \\
28 \\
5 \\
9 \\
7\end{array}$ & $\begin{array}{r}1 \\
0 \\
1 \\
88 \\
8 \\
14 \\
5\end{array}$ & $\begin{array}{r}1 \\
0 \\
1 \\
43 \\
3 \\
12 \\
6\end{array}$ & $\begin{array}{r}3 \\
2 \\
1 \\
35 \\
4 \\
18 \\
7\end{array}$ & $\begin{array}{r}2 \\
2 \\
0 \\
27 \\
8 \\
17 \\
8\end{array}$ & $\begin{array}{r}2 \\
1 \\
1 \\
19 \\
7 \\
10 \\
7\end{array}$ & $\begin{array}{r}2 \\
2 \\
0 \\
15 \\
2 \\
4 \\
4 \\
4\end{array}$ & $\begin{array}{r}8 \\
2 \\
1 \\
25 \\
2 \\
4 \\
4 \\
4\end{array}$ \\
\hline
\end{tabular}

*Data for 19 life companies comprising $97.7 \%$ in 1906 and $96.1 \%$ in 1916 of total assets of all U. S. Companies.

tStock distribution based on data for 49 life companies.
Source: Life Insurance Association of America and Institute of Life Insurance.

a bulge during the thirties which reached its peak in 1932 and 1933 , at the depth of the depression.

As just indicated, the most interesting development which has taken place in the period under review has been in the field of industrial and miscellaneous corporate obligations, almost fully opened up to life insurance investments by the New York amendments of $1928 .{ }^{24}$ The securities of industrial and commercial corporations are, for the most part, unsecured or only partially secured and, therefore, the growth

\footnotetext{
24 Wisconsin, however, did not include industrials in its list until 1935 nor investment in unsecured
} corporate obligations until I939 (Wis. Laws 1935 , c. 260 ; id. I939, c. I4I). 


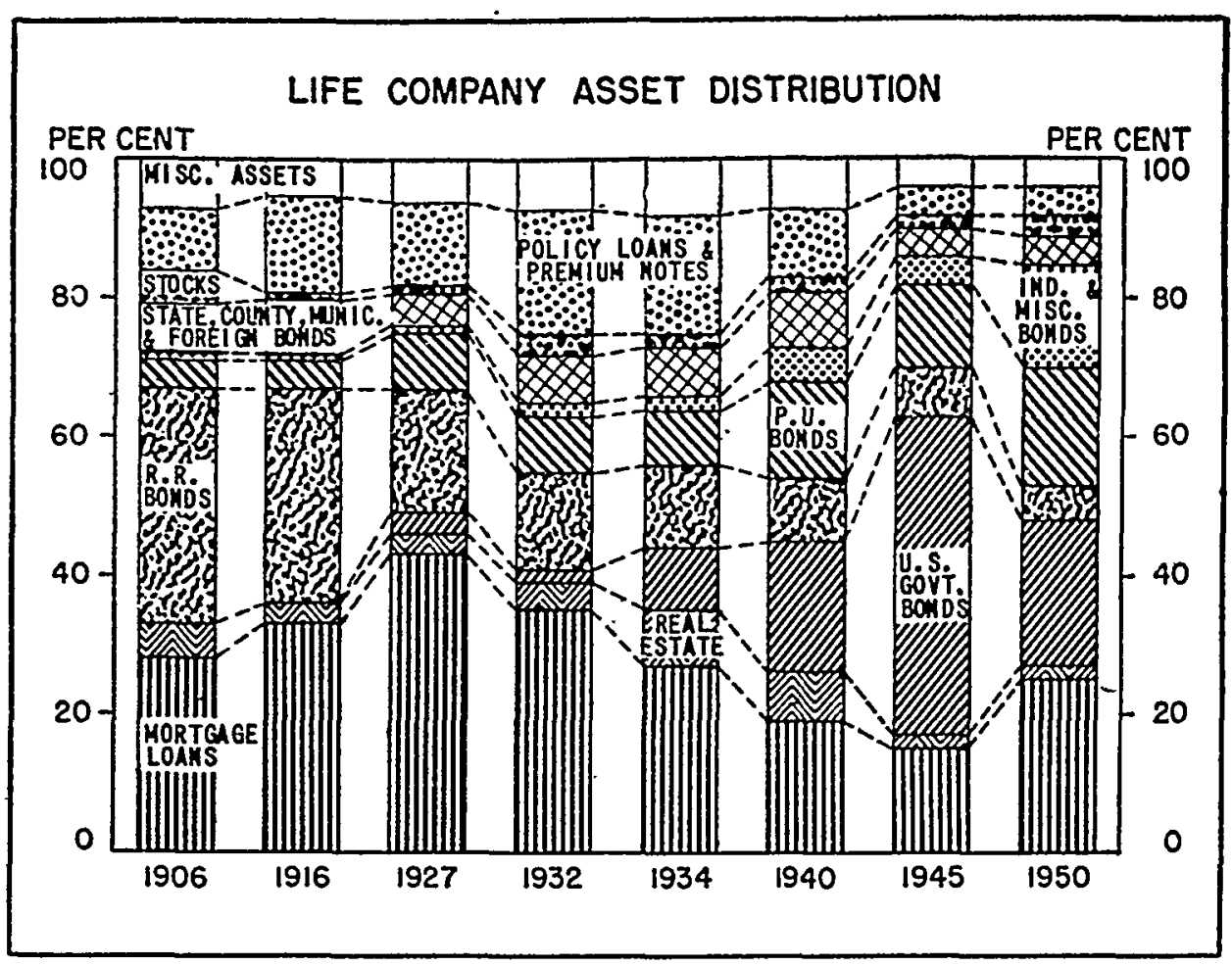

Source: Lifé Insurance Association of America and Institute of Life Insurance.

of this section of the life insurance portfolios signifies, to a large extent, the entry of the industry into the field of unsecured corporate lending.

Investments in the industrial and commercial area remained comparatively low until industry began to emerge from the depths of the depression, and at the end of r934 still comprised only a little more than 400 million dollars, or 2 per cent of assets.

Up to the end of the twenties, there was still a very large supply of long-term corporate debt obligations available to life insurance companies. The life insurance companies were, therefore, in a position where they could pretty well pick and choose between highly rated obligations of large and well-known concerns. The testimony before the Sub-committee on Investment of the Joint Committee on the Economic Report in December, $1949,{ }^{25}$ as well as before the New York State Joint Legislative Committee on Insurance Rates and Regulation in February, $195 \mathrm{I},{ }^{2 B}$ indicates that most of their investments were, in fact, made in relatively large-sized corporations, principally railroads and utilities.

\footnotetext{
${ }^{25}$ Hearings before the Committee on the Economic Report, supra note 18 , at 355 ef seg. Sce also Haughton Bell, Comments on Direct Placement of Securities (paper read before the Association of Life Insurance Counsel, Dec. 13, I949), reprinted as Does Direct Placement of Securities Lead to Corporation Control?, The Commercial and Financial Chronicle, Dec. 22, r949, p. 9.

${ }^{20}$ Minutes of Public Hearing, op. cit. supro, note 17.
} 
A few years later, at the same time the life insurance companies were entering the new industrial field, the railroads had fallen on evil days financially and many of them, operating close to one third of the railroad mileage in the country, had either filed petitions in receivership or for reorganization under Section 77 of the Bankruptcy Act, or were about to do so, so that many securities formerly considered prime insurance company investments had fallen from favor.

Although the public utility field, particularly operating companies, still retained its high investment ratings, the life insurance companies began to explore the new industrial field intensively.

\section{Development of Direct Placements}

It was a very natural circumstance that, under the conditions then prevailing, industrial companies seeking financing began to come directly to the insurance companies, which had ample investment funds available, and to place their securities directly. The larger offerings were placed with a group of insurance companies and the smaller offerings were frequently placed with one company. This was the period of the development of the direct placement.

The direct placement represents a very natural and logical development, since it has brought into long-term lending the direct contact between borrower and lender which has always prevailed in short-term lending. It constituted a method of financing which was particularly useful to the insurance companies when they were exploring, and at first largely experimenting in, what was to them not only a new investment area, but also one which involved a new type of lending. The insurance companies met the situation by greatly expanding their research and analytical staffs so that they could conduct original studies of the new industries to which they were lending. This expansion of expert study and analysis of potential investment areas and prospective individual investments, together with the ever increasing volume of investment information which has been becoming available throughout the whole period under review, has in itself been a most significant development and has immeasurably improved lending technique and the capacity of the companies to cope with the problems involved in new potential investments. The companies also attacked intensively the problem of working out loan agreements which would give them maximum protection in long-term unsecured loans consistent with necessary freedom on the part of the issuer to conduct and expand its business. They also tailored the agreements to meet so far as possible the particular requirements of borrower and lender alike.

Direct placements were speedily found to have advantages which appealed to many borrowers, although they have far from displaced public offerings. Not only did the borrowers benefit from the tailoring of the agreements to fit their particular situations to a greater extent than was customary in public offerings, but they also frequently considered it advantageous to have a loan in the hands of one or a limited number of experienced investors whom they might approach for indenture 
changes if circumstances were altered, rather than to go through the more cumbersome procedure which would be involved in changes in indentures in a widely distributed issue or might even require its refunding. Moreover, as the insurance companies became familiar with the new field of investment, borrowers found it possible to obtain a much speedier decision on the availability of funds and the pricing of the issue than was possible under the public offering procedure, particularly in the light of the requirements of the Securities Act of $1933 .{ }^{27}$ Perhaps even more important from the borrower's standpoint has been the fact that, particularly in recent years with the extremely keen competition among lenders to get their funds invested at better than public debt rates, there has been a trend toward longer and longer forward commitments, generally with payment by the borrower of a commitment fee during the waiting period. Thus, a borrower is able to get assurance a year or more in advance that his financial requirements will be satisfied and at a known interest cost. Furthermore, the expense of issue, both through savings in underwriting fees and in expenses of registration, materially favored direct placements, savings from which the insurance companies often obtained some of the benefit through a slightly improved interest rate. Finally, for a time at least, the fear of possible liabilities imposed by the Securities Act in the case of public offerings, led issuers to favor the direct placement, although amendment of the Act and the failure of suits to materialize later dispelled these fears. ${ }^{28}$

One development in the loan agreements which was a direct outgrowth of the lessons which the depression had taught was the prevalence of provisions for the regular amortization of loans. This feature was introduced not only into agreements covering secured, as well as unsecured, corporate loans, but also into real estate mortgage loans. Also, it was part of the pattern required under the National Housing Act ${ }^{29}$ and, later, by the Veterans Administration, in F.H.A. insured and V.A. guaranteed mortgage loans. F.H.A. loans, which have been acquired in very large volume by the life insurance companies, particularly loans insured under Title II and Title VI of the Act, required complete pay-outs during the period of the loan; and complete pay-outs were generally required also in conventional dwelling loans. In some indentures securing corporate loans, a complete amortization of the loan over its life was required. In other indentures, a partial amortization was mandatory, often coupled with a provision for additional payments out of earnings according to formulae worked out in the individual agreements.

Borrowers and lenders alike recognized the value of the amortization provisions. Indentures covering loans made in direct placements almost invariably provide for at least a substantial reduction of the indebtedness through amortization by the maturity date. Similar provisions have become more common in indentures covering

${ }^{27} 48$ STAT. 74 (I933), I5 U. S. C. \$\$77a-77aa (1946).

${ }^{28} 48$ STAT. 88x, 905 (1934), 15 U. S. C. $\$ 77 \mathrm{k}$ (1946).

${ }_{20} 48$ STAт. I246 (I934), as amended, I2 U. S. C. \$5I70I-r743 (1946). 
public offerings, probably due, in part at least, to the position taken by the life insurance companies in their direct lending.

At this point, it may be interjected that in addition to the trend toward amortization of investments, there has also been a trend on the part of life insurance in. vestors in recent years toward setting up reserves against investments to an extent not previously done. This is true with respect to mortgage loans, as well as corporate investments of all types. It has no relation to direct placements, but is a sound development as investments have been made in wider and wider fields within the legal framework.

The method of direct placement was not only of great help to the insurance companies in exploring and analyzing new lending areas because of the knowledge of the borrower's management it generally enabled them to gain through direct contact, but it also enabled them to investigate new issues to an extent which would have been prohibitively costly had they been forced to take their chances on acquiring a part of an issue, or losing it entirely, if it was offered publicly. As might be expected, therefore, there has been a marked tendency for the insurance companies to make loans to smaller companies than had been the practice before direct placements came into vogue. This was also brought out at the r 949 hearings before the Sub-committee on Investment of the Joint Committee on the Economic Report. ${ }^{30}$

There has been some criticism that through direct placements life insurance companies were gaining undue influence, sometimes termed "control,"31 over borrowers. This arises from a misunderstanding both of the duties of a lender and of the purpose and operation of loan agreements.

Banks, proverbially the short-term lenders, guard their loans with careful provisions designed to assure their repayment. It is even more important that longterm lenders, simply because of the added length of time the loan will be outstanding, should do so. It is especially important that a lender of fiduciary funds should exercise such prudence. Thus it is no more than the duty of a life insurance company, when making a long-term loan, to insert provisions in the loan agreement which will give the greatest assurance possible that the financial practices and position of the borrower which made it an eligible credit will be maintained during the life of the loan. If they are not maintained, the lender must have an opportunity to compel repayment before the borrower's financial situation has deteriorated to a point where this would be impossible. That is all the covenants of a loan agreement seek to do. Contrary to much loose talk and writing on the subject in some quarters

${ }^{30}$ Hearings before the Joint Committee of the Economic Report, supra note 18 , at 355 et seq. See Bell, Does Direct Placement of Sectrities Lead to Corporation Control?, The Commercial and Financial Chronicle, Dec. 22, 1949, p. Ir.

"The use of the word "control" in connection with loan agreements is a complete misuse of the term. "Control" is defined by Webster as synonymous with "direction," "management," "regulation." The position of the borrower in relation to the lender does not even remotely resemble any of these synonyms. 
-and it is noticeable that these criticisms do not emanate from borrowers, who usually appreciate the conditions which must exist and be maintained to induce any experienced lender to extend long-term credit-the loan agreements are designed to give the borrower maximum freedom in the operation and the expansion of its business, consistent with the maintenance of sound financial practices. ${ }^{32}$

\section{Recent Developments in New Investment Forms}

The history of the flow of life insurance funds into new areas of investment as it was participated in by one company, whose experience may be taken as typical, was described in some detail at the I 949 hearings before the Sub-committee on Investment of the Joint Committee on the Economic Report. ${ }^{33}$ Among the more novel fields of corporate financing which have been successfully developed are long-term loans secured by oil and gas leases in proved and producing fields, the extension of subordinated credit to personal finance companies, and new departures in the financing of railroad cars and locomotives and other transportation equipment, including fleets of automobiles and trucks maintained by industrial corporations. ${ }^{34}$ The exploration of new investment areas has not been confined to the industrial and commercial field, but has included the newly developing natural gas transmission industry, other segments of the public utility field, and special revenue bonds issued to finance the construction of public facilities.

These last furnish an interesting chapter in themselves. In the late twenties, a method of financing public facilities by the use of bonds secured only by the revenues to be derived from those facilities, was worked out. Because bonds of this type do not require a pledge of the credit of the state or any of its political subdivisions and, therefore, do not affect debt limits, they have come into considerable vogue. The financing must, of course, be arranged before the facilities are built and, therefore, a commitment for the investment must be made, and at least part of the bonds drawn down upon estimates made by competent engineers, both as to the cost of construction and as to the revenues which would be derived from the facilities. They were expressedly authorized by the investment law of New York in $1940,{ }^{35}$

\footnotetext{
${ }^{32}$ For a general discussion of direct placements, see Rodgers, Purchase by Life Insurance Companies of Securities Privately Offered, 52 Harv. L. Rev. 773 (1939); Fraine, Direct Sale of Security lssues, and discussion, 16 J. AM. Ass'n UnIv. Teschers of Insurance 40 (1949); Bell, supra note 30; E. Raymond Corey, Direct Placement of Corporate Securines (Harvard University, i95I). An excellent compilation of statistical material relating to direct placements made cach year is containcd in the Year Books of Private Placement Financing, prepared by E. V. Hale \& Company, Chicago. This includes, for each issue listed, the names of borrower and lender, type of security, principal amount, interest rate, maturity, intermediary (if any), and purpose of financing.

${ }^{33}$ Testimony of Oliver M. Whipple, Financial Vice President, The Mutual Life Insurance Company of New York, in Hearings before the Joint Committee of the Economic Report, supra note 18, at 355 et seq.

34 The Equitable Life Assurance Society of the United States and The Prudential Insurance Company of America have developed new types of financing railroad locomotives and equipment. The Mutual Life Insurance Company of New York developed a new method of financing fleets of automobiles and trucks.

${ }^{35}$ N. Y. INS. LAW $\$ 8 \mathrm{I}(\mathrm{I})$.
} 
although this amendment may be regarded simply as a clarification of a pre-existing permissive provision. Turnpike bonds, bridge bonds, state university building bonds, and other bonds of this type have been purchased in considerable quantity. No statistics are available as to the amount purchased, but it appeared that by 1945 the total volume of special revenue bonds outstanding was approximately 1.5 billion dollars and at the end of 1950 the total volume of non-guaranteed governmental debt was slightly over 3 billion dollars. ${ }^{36}$ This last figure includes some bonds payable from special taxes and special assessments, but, in view of the volume of turnpike and bridge financing in recent years, probably the bulk of it consists of special revenue bonds.

The suitability of oil and gas production loans secured by leases in proved and producing fields has become established due: (I) to technological developments which have made it possible for geologists to estimate, with substantial accuracy, the minimum amounts of recoverable oil and gas in drilled and developed fields; and (2) to the need for long-term funds in this industry, (a) by reason of state pro-rationing laws which have lengthened the period during which capital investment by the owners of leases is returned, and (b) the advent of the deep well, where the capital investment is far greater than in the shallower wells of 15 years ago. The pro-rationing laws have added to the recovery of oil and, by regulating each owner's production, have further added to the safety of loans by preventing any owner from syphoning off oil in the field more rapidly than his neighbors. They have also tended to stabilize production and prices. The steadily growing importance of oil to the nation's economy and the technological improvements which have been made and are still being made in oil recovery have added to the attractiveness of these loans. Life insurance companies have now been making them for about 8 years, and banks, particularly in the southwest and also some of the large New York City banks, for almost twice that time. ${ }^{37}$ The safety of such loans is, of course, dependent on the care with which they are made and on the competence, as well as the honesty, of the engineers and geologists who make the appraisals. This last point cannot be overemphasized, and such loans should be made only with the best geological and engineering advice obtainable. When so made, they have been eminently successful. The value of the security is much less subject to change, moreover, except as it has tended to become more valuable, than the value of real estate, also determined by appraisal. This type of financing involves none of the risks inherent in the search for oil, wild-catting, or even in the exploration of new fields. The proceeds of a loan are often used for those purposes, but the loan is made on established production.

According to a report issued June I5, 1951 by the Committee on Valuation of

so Govennmental DeBt in 1942-1950 (Bureau of the Census).

${ }^{37}$ Statement of George N. Aldredge, Chairman of the Executive Committee of the First National Bank of Dallas, Texas, at a meeting of the Sub-Committee of the Committee on Valuation of Securities of the National Association of Insurance Commissioners, May 15, 1946. 
Securities of the National Association of Insurance Commissioners, the total principal amount of oil and gas production loans made by insurance companies and outstanding on December 3I, I950 was over 200.75 million dollars (including 63 million dollars representing participations by banks and others). The original total principal amount of these loans was over 244 million dollars.

\section{Housing Projects}

In the late thirties, a new section was added to the law of New York, ${ }^{38}$ permitting life insurance companies to acquire and construct housing projects "to promote and supplement public and private efforts to provide an adequate supply of decent, safe and sanitary dwelling accommodations for persons of low and moderate income and to assist in relieving the housing situation." Although investments in public housing companies had previously been permitted, this marked an innovation, since it permitted direct ownership of housing projects with no element of subsidy or rent limitations involved. Under it several projects have been constructed. Other amendments $^{39}$ have permitted investments in housing projects either directly or through the ownership of stock, debentures or high percentage mortgage bonds, where the power of the state or municipality in assembling the plottage (often involving slum clearance) through eminent domain and a limitation on taxes were provided, together with a maximum return to the investor about equal to the return which could be expected from mortgage loans. The permitted investments include 80 per cent mortgages, otherwise conventional and with no element of guarantee or insurance, on redevelopment projects, including those owned by the tenants as cooperatives. Counterparts of these loans are found in the statutes of New Jersey, Massachusetts, Pennsylvania, Wisconsin, and many other states.

Available statistics on the volume of insurance funds which have gone into rental housing projects which insurance companies own, either directly or through stock of a housing or redevelopment company, as distinguished from those on which they have merely made mortgage loans, are meager. However, according to a release issued by the Institute of Life Insurance on May 18, 1949, the life insurance companies of the country had completed or under way housing projects designed to provide rental housing for 47,000 families with an investment of 475 million dollars of policyholders' reserve funds. Of these, $4^{\mathrm{I}}$ projects, housing 34,500 families and representing an investment of 275 million dollars, had been completed. Additional housing for 12,000 families, representing an investment of 185 million dollars, was under construction; nearly half of this had been completed and was occupied. Additional housing for 500 families, with an investment of 15 million dollars, was planned but not yet under construction. The total projects, completed and planned, aggregated 47. Two were in California, 3 in Connecticut, $I$ in the District of Columbia, I in Florida, I in Maine, I in Maryland, 2 in Massachusetts, 22 in New

${ }^{38}$ N. Y. INs. LAw $\$ 84$, Laws 1938, c. $25, \$ 1$.

${ }^{39}$ N. Y. INs. LAw \$8I.9. 
Jersey, 9 in New York, 3 in Ohio, I in Virginia, and I in Canada. High costs of construction and operation coupled with limitations on rental have substantially curtailed activity in this field.

Income Producing Real Estate-Development of the Purchase and Leaseback

The amendments to the investment laws which permitted the acquisition of other income producing real estate, generally up to 3 per cent to 5 per cent of an insurance company's assets, became general in the three years, 1945, 1946 and 1947, and such amendments are now almost universal. Some of these laws required that the acquisition be made only in conjunction with a long-term lease but, for the most part, there was no such restriction. Nevertheless, the entire period since those laws were enacted has been one in which real estate values were generally considered to be high. In consequence, although many acquisitions have been made under these statutes, comparatively few were made without the assurance that the principal of the investment would be returned through what has come to be known as the purchase-leaseback arrangement. Had the permission been granted in a period when values were considered to be lower, many more investments might well have been made without this precaution.

Under a purchase and leaseback, the insurance company purchases the property, generally either from a prospective tenant or after an arrangement has been worked out with a tenant. It then enters into a lease with the tenant providing for an absolutely net rental, the tenant undertaking to assume all of the expenses and real estate taxes on the property. Such tenants are usually corporations which have a sufficiently high credit rating to justify the expectation that the investment will be recovered. The investor looks both to the credit of the tenant and the intrinsic value of the real estate purchased. 'The investor's relative reliance on the two varies from case to case, but where the intrinsic value of the property, except to the particular tenant, is relatively small, the tenant may have to have a credit rating which would justify the extension of unsecured credit during the normal period of a debenture issue or even longer, since the leases generally run for 5 or to years beyond the usual term of a debenture issue. In such cases, the financial accommodation furnished to the tenant competes, in a sense, with other types of financing and this has to be taken into account in arriving at the rental which may be charged.

Every investment must be made, of course, with an eye to the worst, and in that connection, purchase-leasebacks have an interesting aspect. While it is true that under the Federal Bankruptcy Law, a landlord can prove a claim for the equivalent of only one year's rental in a bankruptcy for liquidation and three years' rental in a Chapter X proceeding, ${ }^{40}$ these purchase and leasebacks have in them elements which give them peculiar strength if they are carefully made. The amount of the claim which can be proved becomes important only if the lease has been rejected by the trustee in bankruptcy and the landlord has received the property back. The bank-

${ }^{40} 30$ STAT. 562 (1898), as amended, and 52 STAT. 893 (I938), II U. S. C. $\$ \$$ ro3, 602 (1946). 
ruptcy of a corporation is usually the means of reorganization, seldom of liquidation. In such a case, the trustee will generally, if the property is essential to the operation, continue to occupy it, and so long as he does, the rental is a charge against the trustee, and therefore a preferred claim. Furthermore, since the leases are made to tenants of extra high credit standing, the rental is usually at a rate lower than that which prevails in the general rental market. In bankruptcy, therefore, the trustee may not only occupy the premises, but may even, because of the advantageous rental, affirm the lease, and if he does, the landlord's claim becomes a preferred claim throughout the entire reorganization proceeding and will then generally continue as an obligation assumed by the reorganized company. Because of the possibility of being relegated to proof for only one or three years' rental, however, the insurance companies as landlords have generally been able to get a better rate of return on their purchaseleaseback investments than they would get if they acquired an unsecured obligation. The differential in yield has been from $1 / 2$ per cent to better than I per cent.

The principal incentives to the tenant for this type of transaction in preference to a security issue are threefold. In the first place, this type of transaction lends itself to the piecemeal financing involved in setting up a series of buildings much better than does the ordinary security issue where, generally, the sale of the entire issue takes place at one time. More important, however, is the fact that, since in bankruptcy the landlord is restricted to proof of three years' rent, the credit of the tenant-corporation is less directly engaged than in a debenture issue and, for that reason, the tenant can generally secure additional financing through the issuance of securities more easily than if he had a debenture issue outstanding for which proof could be made for the full principal amount in the event of bankruptcy. In other words, as it is sometimes put, the tenant remains "debt-free." The third consideration is that, under our system of taxation, many corporations have considered it more advantageous to rent than to own property, since under a rental arrangement the full amount of the rental is a deduction from their income, whereas if they own the property they are limited to depreciation on the improvements plus interest on any indebtedness incurred in the acquisition. So long as the strings of ownership of the tenant are completely cut, there would seem to be no objection to this from a legal standpoint. If, however, the tenant has an option to repurchase, the deductibility of the rental might be questioned, since it would then have some analogy to the mortgagor's equity of redemption, although many of the legal consequences would, of course, be different. ${ }^{41}$

\section{Common Stocks and "Leeway" Provisions}

The other recent developments relate to investments in common stocks and to investments within the discretion of management outside of statutory restrictions.

${ }^{42}$ For a description of the purchase and leaseback device, see Hearings before the Joint Committee on the Economic Report, supra note 18, at 381-387. See also Satterthwaite, supra note 22, and Cary, supra note 22, and John W. McPherson, Some Economic and Legal Aspects of the Purchase and Lease of Real Estate by Life Insurance Companies (paper read before the Association of Life Insurance Counsel, December, 1948). 
Of the $3^{6}$ states which now permit common stock investments, $3^{\text {I }}$ do so by express statutory authorization, with varying limitations both as to aggregate investment, investment in stock of a single corporation, and various types of qualifications regarding eligibility of senior securities, earnings, and dividend records. Fourteen states, including some of the 36 common stock states, place no restrictions on a portion of life insurance investments, and, as already stated, expressly permit, under what is generally known as a "leeway" provision, investments which are not subject to other statutory restrictions. The "leeway" is up to a limited percentage of assets, generally in the neighborhood of 5 per cent, subject also, in some cases, to a limitation expressed as a percentage of surplus, and in some states subject also to the "prudent man" rule.

There has, however, been comparatively little experience, as the figures in Table 5 show, in either common stocks (or, for that matter, in preferred stocks) or in investments within the discretion of management outside the usual life insurance investment patterns. The experiences of two companies in the common stock field were related by the President of one and the First Vice President of the other at the Investment Hearings of the Joint Committee on the Economic Report in $1949,{ }^{42}$ and figures relating to the depression experience of those companies and one other in common stocks are shown in Table 5. There appears to be no statistical material available on investments in the discretion of management outside statutory limitations.

Furthermore, it is unlikely that much resort can be made to the common stock field unless changes are made in the rules adopted by the National Association of Insurance Commissioners for the valuation of stocks. Under the present rules, all stocks, including both common and preferred, must be valued in the annual statements of life insurance companies at their market price on the last day of the year. This is in contrast to the rules for valuation of debt obligations, which, if in good standing, may be valued on an amortized basis, i.e., at cost, adjusted each year so as to produce face value at maturity. Moreover, if a company sets up a reserve against possible fluctuation in the value of these stocks, the reserve, under the present rules of the New York State Insurance Department, must be included in the company's surplus, which, under New York law, ${ }^{43}$ is limited to not more than to per cent of the company's policy reserves and policy liabilities. Until this method of valuation and these rulings with respect to reserves are changed, it seems unlikely that there will be any substantial investment in either common or preferred stocks. The valuation question, including the whole subject of valuation of securities of all types, has been considered by an industry committee for several years and proposals for change, recognizing the long-term character of the life insurance business and including the building up of reserves for loss and valuation fluctuations in the case of both bonds

\footnotetext{
${ }^{42}$ See Hearings before the Joint Committee on the Economic Report, supra note 18, at 242 et seq.; testimony of Dwight L. Clarke, President (now Chairman of the Advisory Council), Occidental Life Insurance Co. of California, id. at 242, and Joseph M. Bryan, First Vice President, Jefferson Standard Life Insurance Co., id. at 273 .

${ }^{43}$ N. Y. INs. LaW \$207.
} 
Law and Contemporary Problems
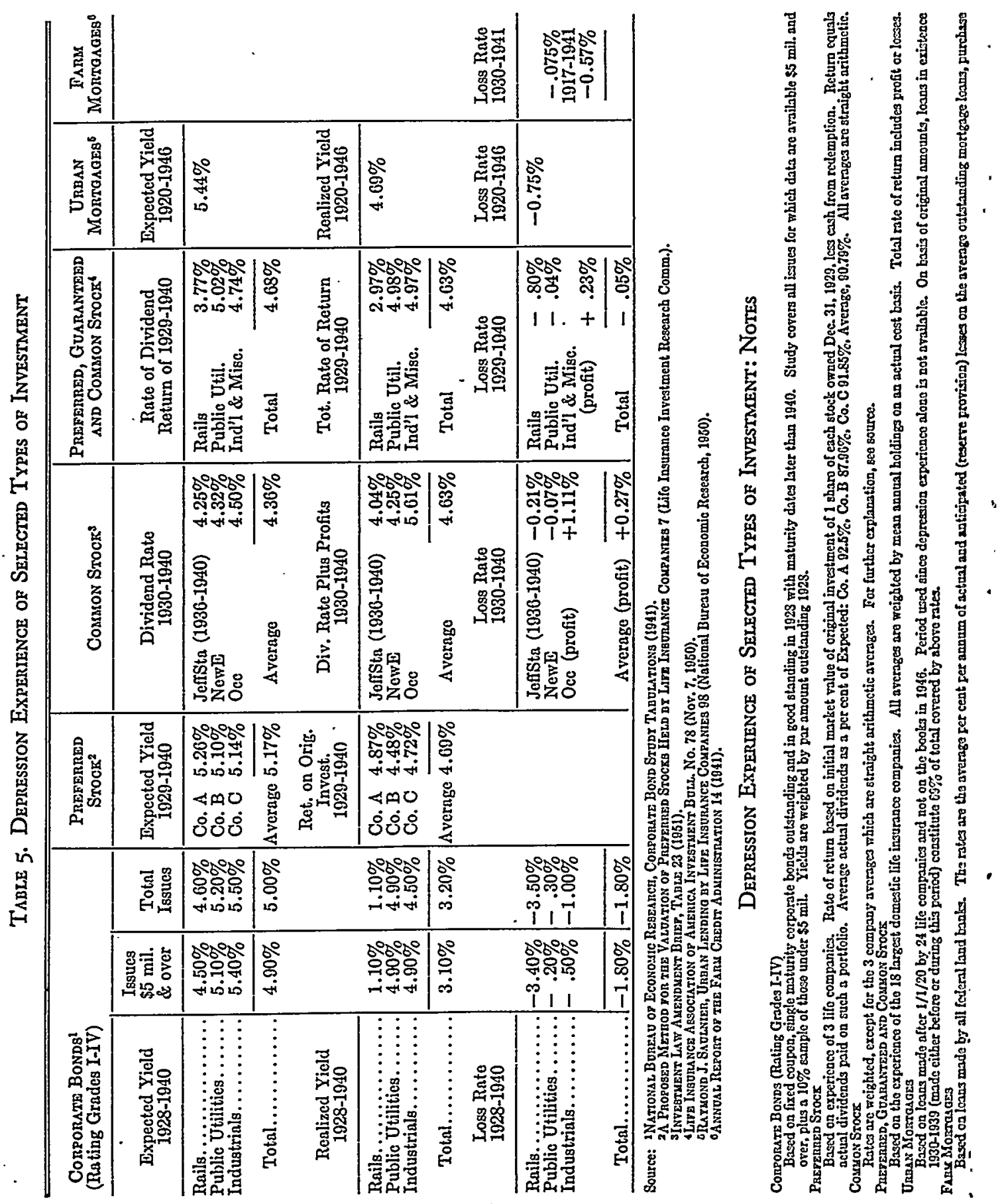
and preferred stocks, have been before the National Association of Insurance Commissioners for several months. ${ }^{44}$ They were considered at the N.A.I.C.'s spring meeting in $195 \mathrm{I}$ and laid over for further consideration. Other proposals were made by the staff of the Sub-committee on the Valuation of Securities of the N.A.I.C. during the summer. A hearing was held before the Sub-committee on both sets of proposals on October 23, and at this writing the subject is being actively considered by representatives of both the industry and the Commissioners. A suggestion which would carry the principles of the industry's proposals further, so as to deal with the problem of valuation of common stocks, not specifically covered in the industry's written proposals although discussed at the October hearing, is included in a recent article analyzing the entire securities' valuation question. ${ }^{45}$

\section{The NeEd for New Investament Outlets}

To dismiss common and preferred stocks with this brief comment, however, would be to ignore the place they seem likely to fill in meeting what has already been referred to as one of the life insurance industry's most pressing problems-the finding of new investment outlets-a problem which confronts not only this industry but also other investors confined by statute mainly to investments in debt obligations.

Perhaps in a world as filled with uncertainty as the one in which we are now living, attempts to peer into the future may be futile and suggestions for the mapping of future courses presumptuous. Nevertheless, we are discussing an industry which necessarily deals with long-term problems requiring long range planning, and since both a major problem and also certain conclusions which may aid in the solution of that problem emerge from the foregoing discussion, it will at least be of interest to project possible future courses of action in the life insurance investment field. Furthermore, the two investment areas just mentioned deserve additional consideration, since they mark an almost revolutionary departure from traditional patterns of life insurance investment, both in law and practice.

Before entering upon a discussion of the future, it would be well to consider further (I) the evidence which points to the existence and the likelihood of continuance of a serious investment problem and (2) the essential function which life insurance investment is intended to fulfill.

Reverting to Tables 2 and 3 (and also the first paper in this symposium), the one point which stands out is that over the past several decades life insurance investments and investments of institutions competing with them have been growing at a rate much faster than the supply of those types of investments which have been traditional for such funds, if low yielding public debt obligations be excluded.

\footnotetext{
"They were forwarded to the Commissioners under cover of a letter of April I0, I95I from the Chairman of the Joint Committee of the American Life Convention and Life Insurance Association of America on Valuation of Securities.

¿Eraine, The Valuation of Security Holdings of Life Insurance Companies, $6 \mathrm{~J}$. Frnance $124 f f$. (195I). See also Hearings before the Joint Committee on the Economic Report, supra note 18, testimony of Dwight Clarke at 246 , and testimony of Joseph M. Bryan at 297.
} 
There appears to be every likelihood that these trends will continue. They rest in part on the rising level of income in the United States, based on increasing productivity, and the increased monetization of savings, trends which have manifested themselves for decades, accentuated by the redistribution of income which has been taking place during the past two decades to a striking degree. The existence of these basic trends and their continuance is dealt with in the first paper in this symposium by Charles $\mathrm{H}$. Schmidt and Eleanor J. Stockwell, and the subject need not be further discussed here.

A further compelling reason, not specifically mentioned above, for seeking new investment outlets is the trend in yields on life insurance assets. It is of the greatest importance that the companies earn the net return on reserves which they have contracted to earn. This is in the neighborhood of 3 per cent. The rate was lowered for new business commencing about 1948, but for many years to come the very great bulk of existing reserves and premium income will pertain to contracts which require the higher rate. The decline in interest rates shown in Chart 2 illustrates what has taken place in the yields. To some extent, this is probably a phase of changing relationship between demand and supply in the traditional investment fields, but whatever the cause, it lends emphasis to the need for new outlets with better yields.

Chart 2

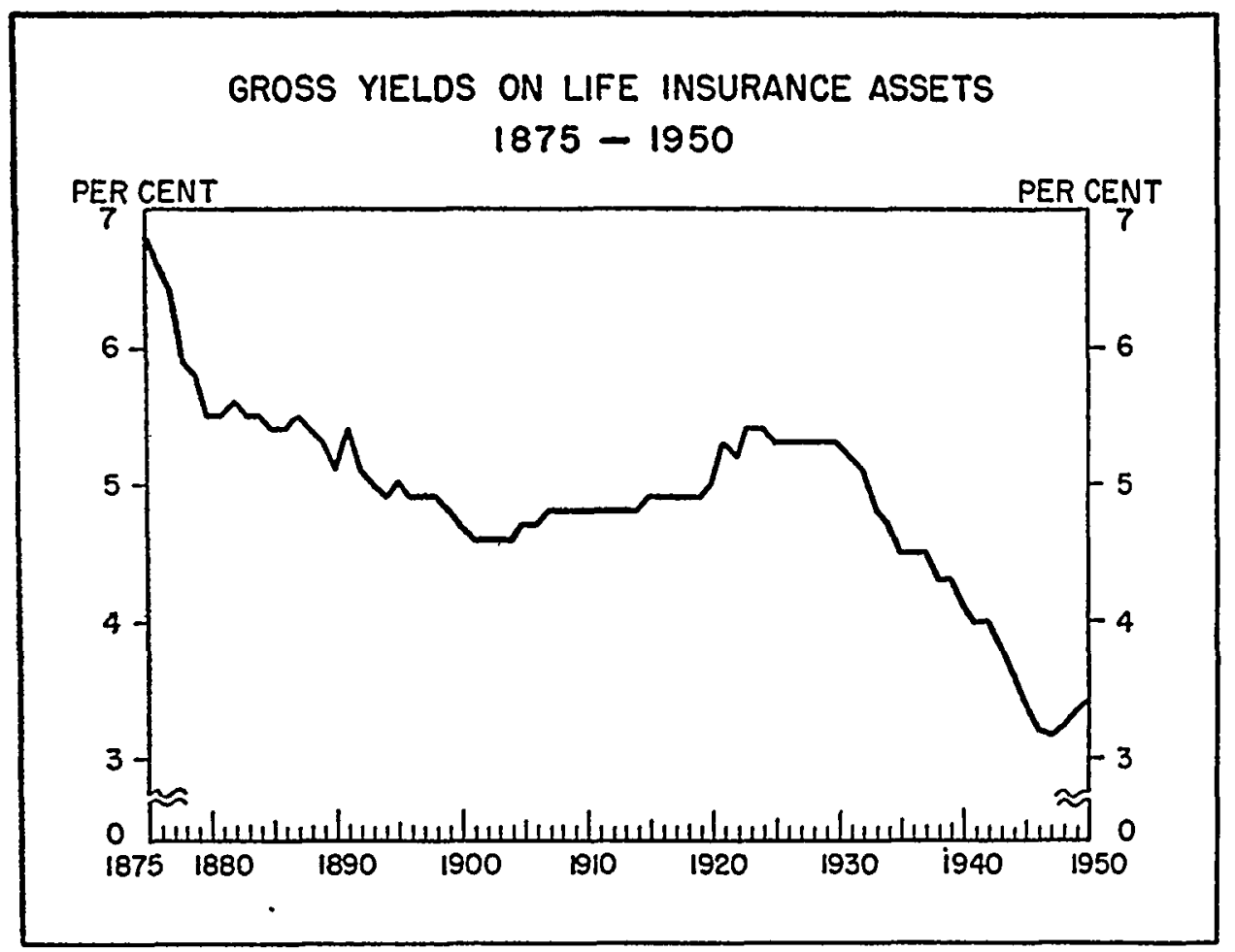

Source: Metropolitan Life Insurance Co. 
Efforts to Get Modification of Legal Restrictions

It has already been indicated that the influence of these trends had begun to make itself felt on life insurance investment when industrial recovery commenced after the depression in the thirties, possibly somewhat earlier. These trends and the consequent stringency in the supply of traditional investment media in relation to demand were also felt by other investors subject to restrictive statutes.

In New York, the mutual savings banks gained some relief in $x 938$ by an amendment to their investment law ${ }^{46}$ which made legal corporate debt obligations approved by the Banking Board, consisting of the Superintendent of Banks and nine members appointed by the Governor. In I949, these banks were permitted to invest their surplus, in the discretion of the management, in corporate obligations not meeting the prescribed statutory tests. ${ }^{47}$ In 1950, they announced that they had studies under way with a view to seeking further amendment permitting surplus to be invested in common stocks, and in I95I such an amendment was introduced in the Legislature, but a full presentation in support of it was not made. The savings banks' studies are continuing, however, with a view to supporting an amendment at the next session of the Legislature.

Trustees have also sought relief. New York trustees for many years had been restricted to the same investments as savings banks. In 1950, after the completion of an elaborate study ${ }^{48}$ carried on over a period of several years, they succeeded in securing an amendment ${ }^{49}$ permitting them to invest up to 35 per cent of the assets of a trust in corporate securities, including common stocks, not made eligible by other sections of the law. The only limitations on such investments were that, at the time of purchase, corporate obligations must be those of a corporation which had some securities currently registered with the Securities and Exchange Commission, and common and preferred stocks, other than bank and life insurance company stocks, must be currently fully listed and registered upon a national securities exchange registered with the Securities and Exchange Commission. ${ }^{50}$.Thus trustees in New York, for many years far more restricted in their investments than life insurance companies, were 2 years ago given a much wider field of investment than the latter.

In 1950, new sections 5-a and 5-b were added to the New York Religious Corporations Law, providing expressly that, subject to any specific limitations applicable to particular denominations or particular funds, the trustees of a religious corporation might invest without regard to the limitations applicable to trust funds; and investments previously made outside of the restricted field were declared lawful.

The efforts by the life insurance companies to liberalize their investment statutes

¿A N. Y. Banking LAW \$235.

${ }^{47}$ Id. $\$ 235.21$.

48 The results of this study have been published in Report ay THE TRUst INvestment Study ConsNIITTEE, op. cit. supra note $2 \mathrm{~T}$.

10 N. Y. PERs. Prop. LAw $\$ 2 I(m)$.

to This was doubtless to assure the availability of adequate investment information. 
have been responsible for numerous amendments chipping away at statutory restrictions on corporate obligations, permitting investment in income producing real estate and common stocks, and introducing the "leeway" provision. Other efforts, such as those to secure permission to make oil production loans to individuals, introduced in New York in I944, have been unsuccessful. Three years ago, a bill further restricting life insurance investments was introduced in the New York Legislature. At the hearings on that bill, which failed of passage, it was not only opposed by the New York companies, but two of them ${ }^{51}$ suggested that a study be made aimed at liberalizing the New York law through enactment of a "leeway" provision. Such a provision, together with a number of other liberalizing amendments, was formally presented to the Legislature in 1950 but no action was taken pending further study. In I95I, an elaborate presentation was made to the New York State Legislature in the form of a report submitted by the two principal industry associations and supported by the testimony of investment officers of a number of the New York companies. ${ }^{52}$ A series of liberalizing amendments was proposed generally similar to those introduced the previous year, including both a provision authorizing investment in common stocks and a "leeway" provision, of which the common stock provision was a part. This resulted in the enactment of a number of amendments, ${ }^{53}$ but New York, true to its post-Armstrong philosophy of statutory limitations, hedged about the new provisions with numerous restrictions. Although it failed to enact the "leeway" provision, pending still further study, made a very important break with tradition in enacting an amendment permitting some investments in common stocks.

Another significant development occurred during the summer of 195 I when Connecticut ${ }^{55}$ raised the percentage of assets which could be invested under its "leeway" provision, which is otherwise totally unrestricted, from 5 per cent to 8 per cent.

Thus, there has been repeated recognition of the fact that, however obscured at times, a major investment problem has existed affecting both the life insurance industry and other fiduciary investors. For the life insurance industry, it appears that, although progress has been made, the measures taken to. date fall far short of a permanent solution.

In determining how best this problem may be met as relates to life insurance

51 The Mutual Life Insurance Company of New York and the New York Life Insurance Company.

Ea See Minutes of Public Hearungs, op. cit. stupra note 17, Feb. 2 and 9, 1951; also id. Jan. 1949, and Feb. 1950. It is quite possible that despite the testimony offered at the 1949 and I950 scssions of the Legislature, neither the Insurance Department nor the Committee of the Legislature considering the amendment fully appreciated the investment problem, obscured as it was by the unusual events in both halves of the decade of the forties. Accordingly, at the suggestion of the then Superintendent of Insurance, the study was made which resulted in the full presentation to the r951 session of the Legislature.

$\ldots 83$ N. Y. INs. LAw $\$ 8 \mathrm{r}$, as amended, N. Y. Laws 195r, c. 400.

si The "leeway" provision was opposed by the new Superintendent of Insurance, at least until further study.

${ }_{55}^{5}$ Pub. Acts I95I, No. 8I. 
investment, it is necessary to consider the function which that investment is expected to perform.

\section{Functions of Life Insurance Investment}

Statutory regulation and company policy regarding life insurance company investment have alike been dominated by two concepts. The first is that the funds the companies hold are to be used to pay the beneficiaries of life insurance policies and that, therefore, safety of principal is a primary consideration. Carried to an extreme this would, of course, mean that the premium monies had to be deposited in the safest banks in the world or invested only in government securities. Neither of these extremes has, however, been adopted, because of the second concept, equally fundamental with the first. The second concept, inherent in the basic principles underlying level premium insurance, is that the funds constituting the reserves for the policy will be invested so as to earn, at compound interest, a return on the basis of which the reserves are calculated and the premiums are fixed. This expectation of yield on investments reduces the initial cost of insurance and keeps it more readily within the reach of the wage-earning family man. Furthermore, in participating insurance. which constitutes about 75 per cent of all of the life insurance outstanding in the United States, ${ }^{56}$ earnings above the expected yield additionally reduce the cost through payments to policyholders in the form of dividends.

The life insurance business is essentially a long-term business, and this has two consequences. On the one hand, it means that the policyholders pay in their premiums over a long period of time and so gradually attain a larger and larger investment in the policy. 'This emphasizes the importance of investing conservatively, but certainly does not minimize the desirability of making the investments as productive as possible for the policyholder, consistent with safety. On the other hand, the business is required to pay out money only on long-term contracts and, despite the policy provisions providing for cash values on surrender and loans against the policies, experience has shown that cash demands against the business do not vary very materially from patterns which can be forecast with reasonable accuracy. They also tend to be offset by a fairly predictable inflow of funds over a long period of years. From this standpoint then, the long-term character of the business gives it a strength which shorter term businesses do not have. It can thus ride out depressions, as it has done with conspicuous success. Although the long-term character of the business could not sustain it against total collapse of investments which it holds, this can sustain it against adverse fuctuations in the value of those investments even though these be sustained over long periods of time, provided only there is ultimate recovery. ${ }^{60 *}$ This should never be lost sight of, and one of the

${ }^{58}$ LIFE Insurance Fact Boor, I95I 9 (Institute of Life Insurance).

sea During the depression, special rules for the valuation of assets were adopted by the NAIC under the compulsions of that period, despite the fact that their then existing standards for determining the amortizability of debt obligations were far less stringent than they are today. These special rules recognized both the long-term character of the life insurance business and the fact that the market values even of debt obligations may be subject to temporary fluctuations. 
problems which managements and regulatory authorities alike may legitimately be expected to solve in the interest of the policyholder, is to take full advantage from an investment standpoint of the life insurance companies' position as long-term investors. It would seem that much more can be done in this direction than has been done in the past.

Finally, it must be borne in mind that far from all of the assets held by life insurance companies are for the payment of death proceeds on existing policies. The companies have also large volumes of funds in the forms both of reserves for ordinary annuities and for payments of policy proceeds to beneficiaries in installments under so-called supplementary contracts or settlement options, sometimes in the form of full fledged annuities and sometimes over much shorter periods of time. Settlement options may be elected by the insured, or, in his discretion, by the beneficiary. The importance of these funds in relation to the investment problem will be discussed in a moment.

\section{Possible New OutLets for Funds}

First, however, a few words should be said regarding the fields in which life insurance companies may hope to find new investments suitable to their needs. There appear to be four possibilities.

(I) In addition to new types of investments and methods of financing, which are constantly being evolved, largely within existing statutory restrictions, there is some additional room in the corporate field, involving particularly newly formed corporations without the earnings' record and other tectinical qualifications presently required by some statutes. The volume of suitable investments in this field is probably not very large. It embraces two areas. The first consists of unsecured obligations of newly formed corporations which, because of their sponsorship or the contracts under which they enter business, appear to have as assured future earnings as many eligible credits already established. An example is an oil or gas pipe line company with, at one end of the line, contracts to purchase oil or gas from an established supplier with adequate reserves and at a price fixed within limits, and at the other end of the line, contracts for the sale of the trans-shipped product at prices related to the cost and adequate to service the new company's obligations. ${ }^{67}$ The second area consists of unsecured obligations of businesses which have been carried on for a long time in unincorporated form, with an earnings' record sufficient to meet the statutory requirement, but which have recently incorporated. The amendment to the New York Insurance Law adopted in $1955^{58}$ requires that the new corporations must have been in existence for at least 2 years, a provision inserted at the insistence of the Insurance Department. It is difficult to see the logic of this limitation, and, since the securities would normally be issued at the time of incorporation, the limitation makes the amendment of little practical value.

\footnotetext{
${ }^{57}$ See Minutes of Public Hedrings, op. cit. supra note 17, Feb. 9, I951.

${ }^{58}$ N. Y. INS. LAw §8I; N. Y. Laws 1951, C. 400.
} 
(2) Loans to unincorporated business of a size comparable to the loans now made to corporations appear also to provide some volume of investments, but, here also, the field is probably rather limited. The most promising area here would appear to be businesses which are still conducted in partnership form or by estates or other unincorporated organizations and oil and gas production loans to individual leaseholders in proved and producing oil and gas fields. Oil and gas in the ground are not real estate under the laws of many states and are, therefore, outside present statutory limits relating to real estate mortgages.

(3) The small loan field, including both business and personal loans, has been largely unexplored, because most of it is beyond the pale of many investment statutes where the loans are not secured by real estate mortgages or pledges of collateral in which insurance companies may invest. Possibly some volume of business in loans secured by other types of security could be developed. In the main, however, life insurance companies do not appear to be adapted to enter either part of this loan field directly, for the simple reason that small business loans and personal loans are, by their nature, to a large extent character loans and the cost of establishing and properly staffing small loan offices all over the United States would be prohibitive even to the largest life insurance companies. At most, it would seem that life insurance companies could enter this field indirectly. Two ways of doing this have been proposed. The first proposal was made by Doctor A. D. H. Kaplan of the Brookings Institution. ${ }^{59}$ It would involve the financing of small business through "capital banks," one of which, he suggested, might be formed in each Federal Reserve district. These capital banks would make loans to and engage in equity financing of small business units, extending their financing only to projects which seemed economically sound, but on somewhat less rigid standards than are applied by local banks. He further suggested that these capital banks be financed by banks, insurance companies, and other investors. ${ }^{60}$ The second proposal is that life insurance companies make small business loans in conjunction with local banks. ${ }^{61}$. One New York company ${ }^{62}$ has endeavored to do so over the past 2 years. Its experiment had necessarily to be conducted within the limits of the New York Insurance Law, requiring that the loans be secured. At the end of the first year of the experiment, only a very small volume of loans had been generated. ${ }^{63}$ This company, joined by the two principal industry associations, endeavored to have the law amended in $195 \mathrm{x}$ so as to permit exploration of this field, but the attempt was unsuccessful.

Life insurance companies now engage somewhat indirectly in providing small loans to corporations and individuals through the financing they do of personal

${ }^{50}$ Hearings before the Joint Committee on the Economic Report, supra note $18, \mathrm{Pt} . \mathrm{x}$, at $45-73,85-98$.

${ }^{\circ}$ One organization which has performed a somewhat similar function is American Research and Development Corporation of Boston, in which at least two life insurance companies, the John Hancock and the State Mutual, now hold stock.

${ }^{61}$ See Hearings before the Joint Committee on the Economic Report, supra note 18, at 1.79 et seq.

as The Metropolitan Life Insurance Company.

${ }^{23}$ See Mrnotes of Public Hearings, op. cit. supra note 17 , at 302 et seq. 
finance companies. Furthermore, some small business and personal loans are made directly by life insurance companies in the form of real estate mortgage loans and policy loans. A study by another New York company ${ }^{64}$ revealed that policy loans are used to a rather surprisingly large extent in the financing of business enterprises of policyholders. The same company, in I946, reduced the interest rate on its policy loans from the statutory maximum, which is the rate ordinarily charged, to prevailing money rates. Though this was not done entirely for investment reasons, it materially increased the amount of the company's loans to policyholders, probably diverting them from banks and other lenders. Nevertheless, although these competive rates have been in existence for 5 years, they have not brought the proportion of the company's assets which were absorbed by policy loans to as much as onehalf of the percentage which those loans absorbed during the whole period from about $\mathrm{x} 9 \mathrm{I2}$ until the market crash. (Companies commenced to make policy loans in volume shortly after the turn of the century and by 1912 they had reached the approximate volume in proportion to assets which they maintained for the next 18 years. At the time of the market crash, they rose sharply, and then began to run off, dropping in 1948 to the lowest point which they had reached percentagewise since they were made mandatory by statutory provision. ${ }^{65}$ The principal explanation seems to be that the requirements of policyholders are now met by their local banks and by personal finance companies which have sprung into prominence during the intervening years.

(4) The other principal area for new investment outlets is in the field of ownership of property. Here the potential is virtually unlimited. The problem is to select suitable investments. Developments in the ownership of real property have already been mentioned. The new departures in the financing of transportation equipment, already referred to, while they may not, in any of the cases mentioned, involve direct ownership, would seem, nevertheless, to place in the insurance companies some part at least of that "bundle of rights, powers ... privileges," and risks which is commonly called ownership. Doubtless investments may advantageously be made in other ways in other types of tangible property. The broadest field for investment in property that immediately suggests itself, however, is through the ownership of common stocks.

\section{SUtTabitity of Common Stocks for Life Insurance Investment}

In considering the suitability of the common stock field, it may be noted at the outset that the Report of the Armstrong Committee did state categorically that common stocks were inappropriate as investments for life insurance companies and recommended that this field be completely closed to them. ${ }^{66}$ That recommendation

\footnotetext{
${ }^{68}$ io Report of the Legislative Insurance Investigattang Committee 389 (1905).

${ }^{64}$ The Mutual Life Insurance Company of New York.

${ }^{\text {as }}$ See Proceedings of the Forty-Fourth Annual Meeting of the Life Insurance Association of AMERICA 4I (1950).
} 
has cast a long shadow over the legislative policy of New York State ${ }^{67}$ and other states as well.

It is perhaps worthwhile to point out four things about that Report. The first is that the evidence on which it was based did support the view that abuses could exist where life insurance companies controlled corporations engaged in other businesses. It did not, however, contain support for the conclusion that common stocks were inherently unsuitable as investments, except in undocumented opinions of two witnesses who stated that they regarded such stocks as "speculative."68 The absence of such support in the evidence for the Committee's conclusion is generally overlooked when the Report is used as an argument, as it not infrequently is, even now, against common stocks. In the second place, the investment areas which the Committee recommended be open to the life insurance companies were, at that time, fully adequate (see 'Table 2), and the life insurance companies' net yield on their assets then averaged $4 \frac{1}{2}$ per cent. $^{69}$ Thirdly, far more information about investments is now available than was dreamed of when the Report was written. Lastly, the Armstrong Committee itself was concerned that the investment field should not be too restrictive. In this connection, especially at a time when the investment field appears unduly constricted, it is worth quoting a paragraph, too frequently unnoticed, from the Report: ${ }^{70}$

It is difficult to draw any satisfactory line with reference to investments in negotiable bonds. It would not be advisable to restrict the investments of life insurance companies in the same manner as those of savings banks. The securities available for investment under such limitations would not be large enough in amount to furnish a sufficient field for the profitable investment of the large accumulations of insurance corporations. It has been feared that such a restriction would prove to be too severe and might operate so far to increase the demand for the favored securities as to preclude a satisfactory rate of income. After much reflection upon this subject the Committee is of opinion that no satisfactory line can be drawn with reference to investments in bonds, other than collateral trust bonds, without hampering the companies in the enjoyment of that reasonable freedom of investment necessary to ensure the return upon which the calculations of their risks are based. Investments in collateral trust bonds, where the greater part of the security consists of the hypothecated stocks of corporations, should not be permitted. But otherwise, the field of investment being limited to evidences of indebtedness, it is believed that the choice of particular securities may better be left to the discretion of the directors.

The framers of the Report thus recognized that a situation, which probably exists today, might come about if the restrictions were too narrow-namely, the companies might be forced to pay for legality, as distinguished from investment quality. They were also willing to leave a broad area of discretion to company

\footnotetext{
${ }^{67}$ See discussion between the Superintendent of Insurance and a member of the Legislative Committee, in Minutes of Public Hearings, op. cit. supra note I7, at 365 et seq.

${ }^{88} 2$ Testimiony Taken by the Legislative Insurance Investigating Committee 1361 (1905); 5 id. at 3889 .

(0) Source: Metropolitan Life Insurance Company.

${ }^{70}$ to Report of the Legislative Insurance Investigating Committee 390-391 (I905).
} 
managements in selection of investments within what were then wide limits. It may be doubted whether they would have looked favorably upon some of the restrictions which have crept into the present investment statutes.

On the investment question, the principal conclusion of the Armstrong Committee was that life insurance companies should purchase securities for investment and not as underwriters or for the control of other industries. It would seem that this conclusion of the Committee is just as sound today as it was when it was written. It should still be followed, but it should now be followed in the light of different conditions which exist and give promise of existing in the future, not only with respect to the relative supply of and demand for investment funds but also in the light of the economic age and development of the country.

Having in mind the long-term nature of the life insurance business, on the one hand, and the fact that the long-term trend of common stocks in this country has been upward, and very substantially upward, there is an argument, the force of which is becoming more and more recognized, that at least a moderate amount of the assets of a life insurance company can be invested with safety, and also with advantage to the policyholders, in common stocks. Yet, because common stocks are far more subject to price fluctuations than are any of the traditional forms of investment of life insurance companies, it cannot be expected, as already indicated, that there will be any substantial investment volume in this field so long as the present valuation methods prevail. This is the first problem to be solved before the common stock field will really be open for life insurance investment, having in mind particularly that the present surplus of life insurance companies averaged at the end of I949 about 7.0 per cent of total assets. ${ }^{71}$

Two other principal problems must also be resolved. The first is to prevent a recurrence of the abuses disclosed by the Armstrong Committee resulting from control by life insurance companies of other corporations through stock ownership. No one would today dispute this objective, and its accomplishment should present no real difficulty. The I95I common stock amendment to the New York Insurance Law, ${ }^{72}$ as proposed by life insurance companies and as adopted, established the limit of the common stock of another corporation which a life insurance company could own at the lesser of 2 per cent of the outstanding common stock or I/ xo of I per cent of the assets of the insurance company, whichever was less. The 2 per cent limitation is probably low. It compares with a to per cent limitation imposed by the same law for many years with respect to preferred stock, increased to 20 per cent in the I95I amendments. Possibly the 2 per cent limitation could safely be raised to 5 per cent. The limitation in terms in the percentage of the assets of the life insurance company which can be invested in the stock of one corporation is also necessary so as to prevent any unduly large acquisition of stock of a large corporation with widely scattered stock ownership, such as the American Telephone and Telegraph Company.

${ }^{72}$ SPECTATOR YeAr Book (1950).

${ }^{73}$ N. Y. INs. Law $\$ 81\left(1_{3}\right)$, N. Y. Laws 195T, c. 400. 
The other problem relates to standards which might be thought to be indicative of the investment quality of common stock. On this point, there is much greater difference of opinion. When the Report in support of amendments to the New York investment law was being prepared for submission to the legislature last winter, 68 senior officers or partners of financial firms or investing institutions were circularized to secure their opinions with regard to the advisability of establishing such standards by law and with regard to what standards, if any, should be established. Of 46 replies received, the great majority, $3^{8}$, believed that no standards should be supplied. This was also the view of the life insurance companies. In view of the attitude of the Insurance Department, however, that standards were essential, some were inserted in the law ${ }^{73}$ relating to the exclusion of bank stocks, stocks of other insurance companies-even fire and accident companies-as well as to the eligibility of senior securities and to the dividend paying and earnings' record of the issuers. Many financial men believe that bank stocks afford one of the most attractive and stable investments in the common stock field. There seems to be some fear of the creation of a "money trust," however limited the amount of the stock of any one bank which might be acquired. This fear would seem to be rather attenuated. To require that only stocks which have paid dividends for to years and have earned on an average of 4 per cent of the par or stated value of their outstanding common stock for an equal length of time places a severe limitation on the timing of transactions. Competent investment officers have thought that life insurance funds, if invested in this field at all, should be invested fairly continuously over a long period of time rather than being invested at any given stage of the market. To place these limitations on stocks which should be purchased, however, would simply mean that life insurance companies might be precluded from buying them in periods of depression when purchase is most advantageous. ${ }^{74}$

There is surprisingly little material available on the relative performance of stocks as compared with investments of the traditional life insurance type. Much of what is available has been summarized, or at least referred to, in the Report in Support of Proposed Amendments to Article 5, Section 81, of the New York Insurance Law; 1951. It appears in Chapter IV and in the numerous appendices in that Report. These also include hypothetical studies which were divorced so far as possible from any influence of hindsight. In addition, the success of investment trusts, both the open-end type and the closed type, and the diversified investment funds of banks is well known. Furthermore, universities have apparently found the investment of part of their endowment funds in common stocks desirable. An article published in the May 12, I95I issue of the Harvard Alumni Bulletin by the present Treasurer

\footnotetext{
${ }^{73}$ Some were inserted in the final draft, just before the Report was filed, making for a strange inconsistency between the reasoning in the text of the Report and the amendments it proposed.

Tt Past earnings and dividend payments may, however, have a direct bearing on the values which could properly be placed upon common stocks and the amount of reserves which might be required against them. Past earnings, therefore, might well be taken into account in connection with the valuation rules to be established.
} 
of Harvard University discloses that the University's investment portfolio increased its holdings of common stock from about 8 per cent of the total portfolio at the turn of the century to almost 40 per cent at the end of 1950 . The article states that as of March 3I, 195I "about $45 \%$ of the market value of the General Fund was invested in common stocks." Certainly from facts such as these it is at least possible to conclude that an industry which, by its very nature, is adapted to placing its funds in long-term investments, such as the life insurance industry is, might have achieved better results for most policyholders if a wider investment pattern had been followed than that to which the industry has been accustomed.

Factors relating to general social and economic interests, as distinguished from the interest of the policyholders of life insurance companies, have probably played a part in previous changes in the legal framework covering life insurance investment. Examples of this are found in the amendments relating to housing companies, to slum clearance and other redevelopment projects, and to direct investment in housing for low and middle income groups. There would seem to be an interest from this broader standpoint in further liberalizing the present limitations of the legal framework. For example, at the conclusion of the T.N.E.C. investigation of life insurance companies, where the particular subject of inquiry was whether they exercised undue economic power, Commissioner Pike, the member of the T.N.E.C. representing the S.E.C., which was the agency in immediate charge of the life insurance investigation, recommended that they be given additional power to invest in common stocks because of the need of the economy for additional equity money. ${ }^{75}$ The needs of the economy along these lines, especially in relation to small business, concerned the Sub-committee on Investment of the Joint Committee on the Economic Report. Certainly no one familiar with the collapse of the debt-heavy financial structures of so many railroads during the thirties would deny that excessive use of debt financing in relation to total capitalization can produce serious instability in corporate structures, and under some circumstances, in the whole economy. It would also scarcely be denied that, because of the broad investment interest which the life insurance industry has throughout the whole range of the economy, it is in the interest of policyholders themselves, as policyholders, that corporate financing shall proceed along sound lines and that there shall be an adequate supply of equity capital to keep the corporate structures in balance. Because of the clear interest of the life insurance companies, as investors, in the health of the economy as a whole, they can also not be oblivious of the needs of small business for capital and would undoubtedly be prepared to aid in supplying it, provided some method of participation, such as one of those discussed earlier, could be developed into a safe medium for investment. At the same time, it would seem appropriate to point out that there is a marked distinction between equity capital and the financing of established small business, on the one hand, and venture capital, on the other, and it would not seem

\footnotetext{
${ }^{75}$ Final Report and Recommendations of the Temporary Nationat. Economic Committee.
} 567-574 (77th Cong., Ist Sess. 194r). 
to be in either the general interest or the interest of policyholders to require, or expect, as some have seemed to do, that life insurance companies furnish the latter. But this could lead us far afield. In this paper, we have been considering the investment problem mainly from the standpoint of the interests of the policyholders themselves and the return to them on the companies' investments. From that standpoint, the need for liberalization of existing limitations seems apparent. In this paragraph, we simply wish to point out that, from a much broader standpoint, such liberalization appears desirable. To put it conservatively, it would certainly seem to be not against the public interest, nor against the interests of the policyholders either as members of the general public or as policyholders, to permit wider latitude.

\section{The "Leeway" Provision-Management Discretion}

The second major trend in recent legislation is to give management greater discretion in the selection of investments under the so-called "leeway" provisions. Such a provision was enacted in Connecticut, Indiana, and Wisconsin in I945; Delaware, Illinois, Nebraska, North Dakota, Ohio, Oregon, Utah, and Washington in 1947; Louisiana in 1948; New Hampshire in 1949; and Pennsylvania in $1955^{{ }^{76}}$ As already stated, the existing provision was expanded in Connecticut in I95I.

Under restrictive investment statutes these provisions can perform two very useful functions. In the first place, every restrictive statute necessarily draws lines inside of which investments are legal and outside of which investments are illegal. Necessarily, these lines, once laid down, become fixed and unalterable. Nevertheless, there will be cases of borderline legality. These are not infrequently totally unrelated to borderline investment quality. Often investments inside the lines are unsound, as were many railroad bonds and real estate mortgages in the late twenties. On the other hand, thoroughly sound investments can be found outside the statutory

\footnotetext{
${ }^{70}$ Conn. Gen. Stat. \$6I7I (I949); Ind. Ann. Stat. \$39-4202(20) (Supp. I949); Wis. Stat. \$206. 34 (m) (1947); Del. Laws I947, c. 200, §I; Ill. ANn. Stat. \$66.800(8) (Cum. Supp. I949); NeB. REv. StAт. \$44-311.03 (Supp. I947); N. D. Laws 1947, c. 217; Ohro GeN. Code ANN. \$9357-2 (Supp. I950); Ore. Comp. Laws Ann. \$IoI-408(5)(k) (Supp. 1947); UTAH Code ANn. \$43-13-25 (Supp. 195I); Wash. Laws 1947, c. 79, §13.24, p. 312; LA. Gen. Stat. ANN. \$4018.04(xI)(h) (Supp. 1949); N. H. Laws 1949, c. 48; Pa. Laws I95x, Acts 245.

In some states, investments are permitted outside of statutory limitations, provided the Insurance Commissioner approves them. This is not a new development, but such statutes are found in Arkansas, Georgia, Minnesota, North Carolina, Oklahoma, Tennessee, Virginia, and Washington, one dating back as far as the last century." These statutes are open to two criticisms. In the first place, they confuse the essential differences between the respective functions and responsibilities of regulatory officials and company managements. The former are responsible for administering rules laid down by state legislatures. The latter are responsible for producing a product at the lowest cost. This is peculiarly a function of management, and it is contrary to the whole theory of private enterprise that the state should participate in this function. It would also seem unwise to divide the responsibility. In the second place, these statutes cast an unfair burden on the regulatory authorities. Although they are often exceedingly able and devoted public servants, they would generally be the first to admit that they are not financial experts, and they should, therefore, not be required to assume any responsibility for approving investments.

The list of leeway provisions and the reference to statutes permitting investments with Insurance Commissioner approval were kindly furnished by Charles A. Van Orden, Jr., Esq., Attorney, Life Insurance Association of America.
} 
lines. ${ }^{77}$ Management has the responsibility of exercising a negative investment judgment to reject unsound investments which are inside the statutory lines, and it should have an affirmative discretion, at least to some extent, to purchase sound investments which happen to fall outside the fixed and rigid statutory lines. Furthermore, since investment patterns are constantly changing, there is sometimes a legal question regarding the side of the line on which a particular investment falls. Sometimes these questions cannot be speedily resolved, whereas the investment will be lost if the decision to acquire it is not speedily made. The "leeway" provision gives this latitude. Furthermore, it provides, to a limited extent, room for much needed investment experiment to develop new investment outlets.

This brings us to a consideration of the wisdom, under present conditions, of restrictive investment statutes. A review of the performance of investments which have been legal under the more restrictive type of statute which has governed life insurance investments raises a serious question as to the wisdom of that type of statute. The casualties in the area of obligations secured by steel, brick, and mortar during the depression are notorious. Nowhere in the whole area of corporate obligations did defaults even begin to approximate those which occurred among railroad bonds, which have always been the oustanding example of secured obligations. Furthermore, defaults in the real estate mortgage loan field were also widespread and serious.

Although life insurance companies have not yet had to weather the acid test of a depression in their industrial-for the large part unsecured-corporate obligations, the record of such obligations during the depression was, of course, made and it compares very favorably with the record of other corporate obligations, largely secured, as may be seen from Table 5 .

Considering further the experience under restrictive investment statutes, it is pertinent to point out that in its "Study of Legal Reserve Life Insurance Companies" in Monograph No. 28, Section X, the Temporary National Economic Committee in commenting on life insurance company failures ${ }^{78}$ attributed as among the causes of such failures, improper mortgages loans and even extravagant investments in home office buildings. It should be pointed out, also, that such failures were, in the Committee's opinion, due, for the most part, to investment policies "which were tantamount to fraud and breach of trust on the part of company managements."70

The importance of management in the selection of investments cannot be overemphasized. Whatever standards or restrictions a statute may set up to qualify investments as legal, the statutory provisions cannot begin to measure investment quality. The inability of the most restrictive type of statute to guard against what proved to be unsound investments may well find a counterpart in the inadequacy of

${ }^{77}$ See testimony of Oliver M. Whipple in Hearings before the loint Committee of the Economic Report, supra note I8, at 355 et seq., and Stuart F. Silloway, in Minutes of Public Hesrings, op. cit. stipra note I7.

${ }^{78}$ See particularly pages $118,125,128$, and 134 of the Monograph.

${ }^{70}$ Id. at 134 . 
the present statutes which contain earnings' tests. In a period of as long continued economic prosperity as that in which we now find ourselves, these tests are almost completely unselective and the obligations of almost any corporation which has been in existence for 5 years would now be likely to meet the statutory tests.

The tests applied by competent life insurance managements are actually far more searching. They take into account the demand for the product of the issuer, and the likelihood of the continuance of that demand; the quality of its management, its position in its own industry and as against possibly competing products of other industries, the strength of its financial position, and the financial policies which it has pursued in the past. It will readily be seen that these tests involve weights and measures that could not successfully be incorporated in a law. Such important qualities, which management must weigh and measure, become imponderables from the statutory standpoint. Thus, life insurance managements must constantly exercise the responsibility of reviewing investments which fall within the legal framework of the statutes. It is a responsibility which is exercised daily; many more investment offers are rejected than accepted. ${ }^{80}$ Probably a majority of those rejected comply fully with legal requirements, although statistics on the point are not available, even based on a sampling, since the investigation of offerings rejected on investment grounds generally does not get to the point where their legal status is determined.

Those who have advocated the continuation of restrictive statutes have often pointed to the outstanding record of solvency maintained by life insurance companies. Perhaps it may, without impropriety, be suggested that the actuaries on whose recommendations managements have established premiums, and the doctors, scientists, technologists, businessmen, and all who have contributed, both through the remarkable advances in medicine and a sharply rising standard of living, to the ever-improving mortality trend may justify an even stronger claim to establishing this record than the restrictive investment statutes. Furthermore, management policy has, for the most part, generally followed the lines laid down by the statutes, even in states where wider discretion has been possible. Again, however, this must be attributed in at least some degree to the valuation requirements and the attitude of state regulatory authorities.

There is little to be gained, however, by speculating on what the results would have been in the past had life insurance companies been permitted to follow broader investment patterns. Perhaps the restrictive statutes have prevented some failures, although this would also have depended on the valuation methods which might have been employed and the requirements regarding reserves had the broader patterns been permitted..$^{80 x}$ On the other hand, if the broader discretion had been wisely exercised,

${ }^{80}$ Testimony of Stuart F. Silloway in Minutes of Public Hearings, op. cit. supra note I7.

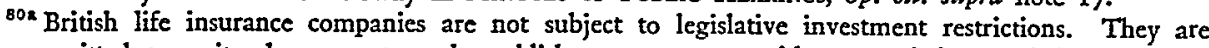
also permitted to write down assets and establish asset reserves without restriction. Their record for solvency has been excellent. 
the result might have been substantial reduction in the cost of insurance to policyholders and larger installment payments to their beneficiaries. But if our analysis of existing trends is correct, the industry is now confronted with a situation which did not exist when the narrower molds were cast. It now appears that it may soon have the practical alternative of investing more and more heavily in Government bonds or of branching out into fields which, though new to it, have been successfully developed by others who have made investment a profession. With the high degree of overcrowding which now exists in the traditional investment fields, this choice could, in a very short space of time, take on the form of stark necessity.

In private conversation, some, who adhere most fixedly to the philosophy of restrictive statutes, will say that they have no fear of practices which might be followed by the larger companies if the restrictions were relaxed but they are afraid that small companies might not be equipped to exercise their new freedom. Perhaps a brave soul may one day appear who will have the hardihood to champion the proposal that statutes should be accommodated to permitting business organizations to do the best jobs they are capable of doing, even though this may involve granting to larger organizations powers which are denied to smaller organizations. To find such a person in the political field today might, however, require the services of a Diogenes with the patience of Job. It is at least notable that this suggestion for the solution of the problem, if there be one, has not been audible, even in private conversation. Taking the world as we find it today-but without abandoning all hope for a better-we therefore think it is fortunate that there is another way out of the imagined difficulty. This is found in the fact that there is now no dearth of competent investment advice which can be readily obtained by any company from investment counsel, investment bankers, and other financial experts. This type of advisory service is not infrequently utilized on a professional basis by even the largest companies when a situation arises which their own staffs are not adequately equipped to handle, and would seem to be within easy reach of all companies to whatever extent they may require it.

It does not seem in any way necessary to tear down all of the restrictive barriers which have been thrown up around life insurance investments in one fell swoop. In an industry which has lived as long as the life insurance business has within a limited investment area with little experience beyond it, it would seem unwise to break away from the patterns of the past too rapidly; nor, indeed, have the life insurance companies themselves expressed any desire to do so. They are fully aware that they are investors of fiduciary funds, and that such investments should be made only with the exercise of the best judgment that can be brought to bear in areas in which that judgment is truly informed. Even though the legal framework were to be materially altered now, it is not likely that practices would change with undue rapidity. Fields new to the life insurance companies would have to be explored and first-hand knowledge of them gained. 
The companies themselves asked the New York Legislature this year for permission to invest only up to 5 per cent of their assets and not more than two-thirds of their surplus, whichever was less, in the unrestricted field, and, under the proposal, this field included common stocks. This would doubtless not be the ultimate extent to which freedom from restrictions may become necessary, but the additional latitude could, and should, be given progressively as experience in new fields is gained under the permission previously given. That is the program which the companies have advocated, and it seems both moderate and sound. Great advances have been made in recent years as more and more states have removed, in part at least, the barrier to common stocks and to other investments within the discretion of management. It may be hoped that additional latitude, particularly in the latter direction, may be given in the near future. The rate of change should be linked to the requirements of the business, but changes should not be delayed to the point where the companies would be tempted to explore newly opened fields too speedily or to enter them without having had adequate time to build up the reserves which prudence requires. The life insurance business is indeed a long-term business, and practical results from changes in investment limitations in the form of higher yields on insurance assets cannot be expected to show themselves save over a period of years.

\section{Contract Holders' Discretton}

If there is one portion of the life insurance funds with respect to which greater latitude might be given much more speedily, it is the portion of the funds which constitutes the reserve for annuities and for optional settlements involving payment of policy proceeds in installments over a period of time. It would seem that no valid objection could be made even by the most ardent advocates of restrictive statutes or the most confirmed exponents of legislative paternalism ${ }^{81}$ if the holders of the contracts for whose benefit these funds are held and who have the legal power and competence to do so were given the right to determine whether the funds should be invested under the restrictions applicable to other life insurance funds or within the discretion of management. This idea has been studied by one company ${ }^{82}$ without the discovery of any serious problems regarding its feasibility. The funds applicable to the contracts whose holders so elected would simply be segregated from the remainder of the company funds. The election of the unrestricted funds would neces-

${ }^{81}$ It would perhaps be kinder to say those people who just like to hark back to the good old days when the vice president in charge of investments could turn to the other member of his department and ask her to get a couple of investment houses on the phone so that he could place the order for the biwcekly supply of triple $A 5 \%$ bonds.

${ }^{82}$ The Mutual Life Insurance Company of New York. After this paper had been written, but before final proofs had been corrected, Teachers Insurance and Annuity Association of America announced a plan which would permit holders of its annuity contracts to have up to one-half of their premiums turned over for investment to a new corporation, to be formed under special charter, which would be empowered to invest in common stocks. The new corporation would pay variable annuities, each payment depending on the value of the "units" (similar to shares in an open-end investment trust) payable on the payment date. The plan contemplates that the new corporation will invest primarily in common stocks and emphasizes the principle of dollar averaging. 
sarily do away with guaranteed rates of interest under the contracts, and those who participated in the unrestricted fund would be in substantially the same position as the participants in open-end investment trusts. The valuation question does not arise and under this proposal the new investment fields would be opened before that problem is solved. The reserves for annuities and optional settlements aggregated at the end of 1950 , approximately 21.6 per cent, or about 13.8 billion dollars, of life insurance assets. ${ }^{83}$

In the course of the study made by the Trust Investment Committee in New York, the I 6 banks represented on the Committee, Io from New York City and 6 from other parts of the state, ranging from very moderate size to the large New York City institutions, made a survey covering more than 20,000 separate trusts in their own accounts, with an aggregate value of more than 4 billion dollars. These trusts were classified as to restricted and unrestricted, both by volume and number. It was found that, with considerable expected variation in the distribution of restricted and unrestricted trusts among the individual institutions, the proportion of trusts limited to legal investments was only about 20 per cent by volume and not much more than 30 per cent by number of accounts. In addition, the Committee made an inquiry among the members of the bar, writing more than a hundred letters to attorneys in New York City and other places, who were understood to have had experience in probate practice. They asked the attorneys to give an indication of the trend with respect to investment provisions in wills prepared in their offices during the preceding 5 years. The response, received from approximately two-thirds of those to whom letters were written, indicated an overwhelming trend toward unrestricted investments. If this is any indication of the preference of the public as between restricted and unrestricted investments, it might be found that a very large percentage of the holders of annuities and supplementary contracts issued by life insurance companies would express a like preference.

There is also a possibility that life insurance policies might be issued on two different bases, one with reserves invested in accordance with legal restrictions and the other with reserves invested in unlimited funds. There would probably be more difficulties and more statutory amendments involved in this than there would be in the unrestricted investment of supplementary contract and annuity reserves. ${ }^{84}$

\section{ConcLusion}

During the twenties there came to be almost universal recognition that earning power was at least as important as physical security in judging the investment quality of a corporate obligation. Judged by the experience of the depression, this recog-

ss The Institute of Life Insurance.

84 See testimony of Dwight L. Clarke, in Hearings before the Joint Committee on the Economic Report, supra note 18 , at 248 . For an interesting article on the subject, see Harry C. Sauvain, Some Economic Considerations Affecting Investment Policy, Proceedings of the Forty-Second Annulu MeETiNg of the American Life Convention 308 (1947). 
nition came none too soon. The trend now seems to be to give more and more recognition to the importance of responsible management in judging the quality of investments of all types. In a system dedicated, as the American system is, to the principle of free institutions and competitive selection, this seems to be a most salutary trend. When legislatures consider the investment problem they might well take into account the remarkable accomplishments that have been achieved in the fields of medicine, science, technology, and industrial organization and production, where research, analysis, and ingenuity have not been fettered by external restrictions. 